\title{
Thermal history of the early Miocene Waitemata Basin and adjacent Waipapa Group, North Island, New Zealand
}

\author{
ASAF RAZA ${ }^{1}$ \\ RODERICK W. BROWN ${ }^{1}$ \\ PETER F. BALLANCE ${ }^{2}$ \\ KEVIN C. HILL ${ }^{1}$ \\ PETER J. J. KAMP ${ }^{3}$ \\ ${ }^{1}$ Department of Earth Sciences \\ La Trobe University \\ Bundoora, Victoria, Australia \\ ${ }^{2}$ Department of Geology \\ The University of Auckland \\ Private Bag 92019 \\ Auckland, New Zealand \\ ${ }^{3}$ Department of Earth Sciences \\ The University of Waikato \\ Private Bag 3105 \\ Hamilton, New Zealand
}

\begin{abstract}
Apatite fission track (AFT) and vitrinite reflectance (VR) data for early Miocene outcrops from the Waitemata Basin reveal that the basin sequence was subjected to shallow burial before denudation. AFT results suggest that the total sediment thickness within the basin was $\leq 1 \mathrm{~km}$ and maximum paleotemperatures during burial never exceeded c. $60^{\circ} \mathrm{C}$. Statistical analyses of the detrital AFT ages distinguish four dominant sources of sediment supply: contemporaneous volcanism; metagreywacke rocks of the Waipapa Group; the Northland Allochthon; and an unidentified source south of the basin.

The apatite and zircon fission track results from the Waipapa Group rocks (Gondwana Terrane) adjacent to the basin suggest two discrete phases of accelerated cooling: the first during the early Cretaceous (c. $117 \mathrm{Ma}$ ) and the second during the mid Cretaceous (c. $84 \mathrm{Ma}$ ). These events probably reflect key stages in the tectonic development of the New Zealand microcontinent during the Cretaceous period, the earlier event being related to the climax of compressional deformation (Rangitata Orogeny) and the latter to extensional tectonism associated with the opening of the Tasman Sea. Waipapa Group rocks now exposed at the surface cooled from maximum paleotemperatures of c. $250^{\circ} \mathrm{C}$ at an estimated rate of c. $180-36^{\circ} \mathrm{C} / \mathrm{m}$.y., involving substantial denudation.
\end{abstract}

A previous version of this paper was originally published in New Zealand Journal of Geology and Geophysics Vol. 42, No. 2. Because that version contained errors in the figures, a corrected version of the paper is reprinted here.

G98010

Received 7 May 1998; accepted 19 November 1998
Keywords Waitemata Basin; fission track analysis; geochronology; vitrinite reflectance; provenance; Waipapa Group; Miocene; mid Cretaceous; continental extension

\section{INTRODUCTION}

The Waitemata Basin is an inter-arc basin which developed during the early Miocene in response to renewed subduction along the northeastern margin of New Zealand (Hayward 1993). Its volcanogenic flysch succession covers an area of c. $8000 \mathrm{~km}^{2}$ centred on Auckland (Fig. 1), and unconformably overlies complexly deformed autochthonous and allochthonous sedimentary sequences of Mesozoic-Tertiary age, comprising three distinct units-the Waipapa Group, Northland Allochthon, and Te Kuiti Group. The basin sequence is exposed extensively along the present shoreline.

Apatite fission track (AFT) analysis in conjunction with vitrinite reflectance (VR) data can be used to evaluate maximum paleotemperatures affecting basin sediments (Green et al. 1989). If basinal temperatures never exceeded $60^{\circ} \mathrm{C}$, the apatites will essentially preserve the inherited ages and provide important information about the provenance of the sediment and the cooling histories of source terranes. The objective of this study is to appraise the thermal history of the Waitemata Basin by assessing the degree of coalification of dispersed organic matter (VR) and fission track annealing in detrital apatites. Both VR and AFT results confirm that the basin fill has been subjected only to low $\left(<60^{\circ} \mathrm{C}\right)$ temperatures due to shallow burial. Therefore, we have concentrated on unravelling the provenance of the basin sediments. Fission track ages have been measured on the apatite grains both from the basin and from the potential source rocks outcropping within the region. Measured apparent ages are statistically separated into discrete populations, and the mean age of each population is compared with the cooling ages of the likely source areas.

A previous detailed study of heavy mineral suites from the sandstone beds of the basin elucidated considerable information about their provenance (Hayward \& Smale 1992). AFT analysis is potentially useful because it can provide: (1) independent evidence about the potential source areas for the basin; (2) independent evidence for early Miocene volcanic activity; (3) chronological evidence for the variation in source area across the basin; and (4) new constraints on the thermal history of the Waipapa Group (one of the source terranes).

\section{REGIONAL TECTONIC SETTING AND GEOLOGY}

Because of its almost continuous proximity to plate boundaries, the New Zealand microcontinent has been tectonically active from the Paleozoic to the Present (Kamp 1986a; Bradshaw 1989; Spörli \& Ballance 1989). Before its separation from the Australian plate in the late Mesozoic, 


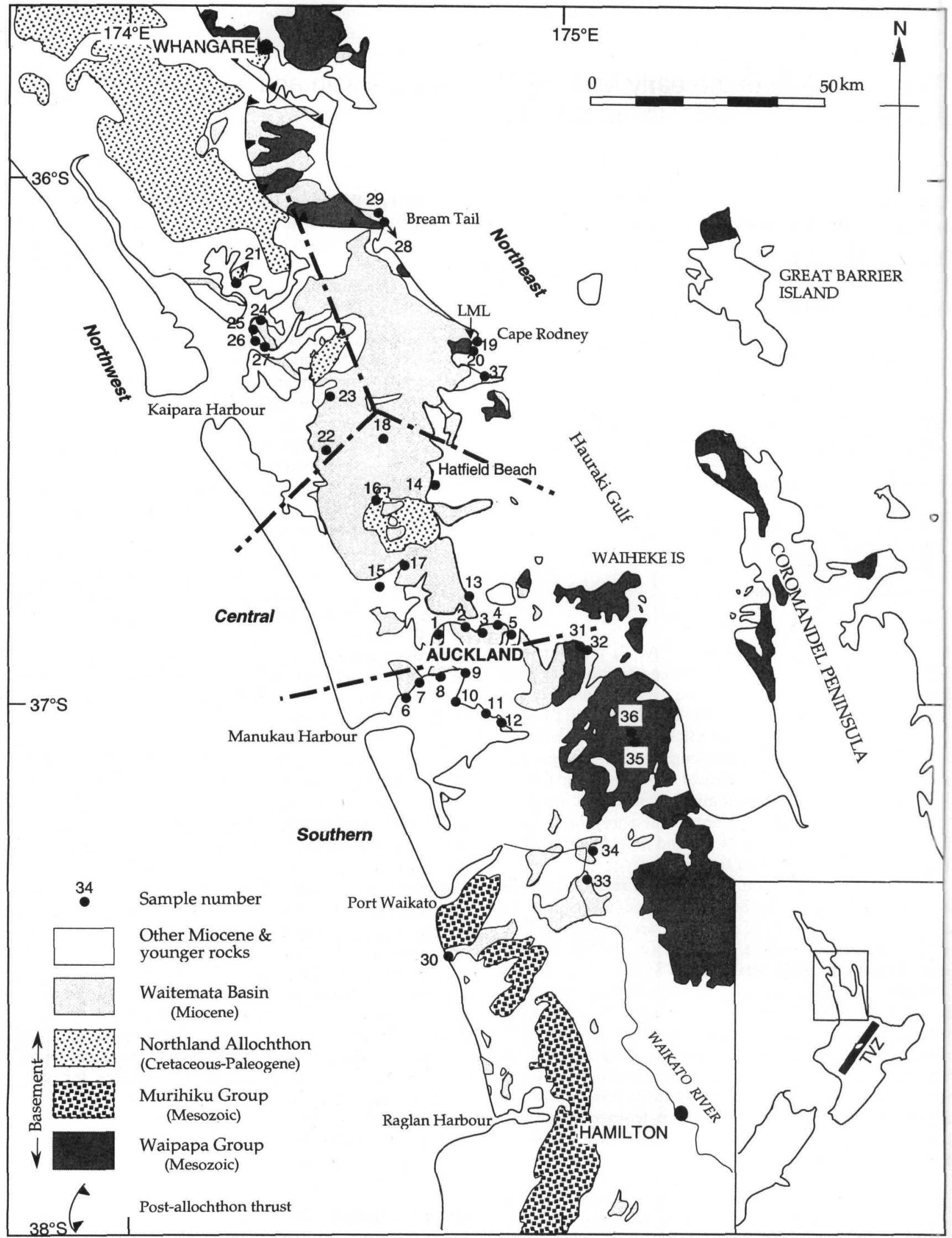

Fig. 1 Simplified geological map of the Northland region showing areas of Waitemata Basin outcrops and basement rocks. Numbers indicate sample localities. The southern, central, northwest, and northeast regions were defined arbitrarily to interpret AFTA provenance data. TVZ, Taupo Volcanic Zone; LML, Leigh Marine Laboratory. 
New Zealand was part of the eastern edge of Gondwana and the subduction zone along its Pacific margin. During the mid Cretaceous (c. $105 \mathrm{Ma}$, Bradshaw 1989), this tectonic setting was interrupted. Subduction ceased beneath New Zealand as a result of collision between the Pacific-Phoenix spreading ridge and the subduction zone along eastern Gondwana (Bradshaw 1989; Spörli \& Ballance 1989). This event was closely followed by a switch from convergence to extension (Laird 1994, 1996). The onset of seafloor spreading in the Tasman Sea at c. $80 \mathrm{Ma}$ (Weissel \& Hayes 1977) records the time when New Zealand finally separated from Australia.

Extension was followed by a prolonged period (c. 80 25 m.y.) of relative tectonic quiescence and slow thermal subsidence. However, from the late Eocene to mid Oligocene, renewed extension occurred along the western margin of New Zealand in response to the propagation of the Southeast Indian Ocean Ridge into southern New Zealand (Kamp 1986b). By the end of the Oligocene, marine carbonate deposition was taking place over most of the New Zealand region and a thick, fining-upward, passive margin sediment wedge had accumulated along the Pacific seaboard (Ballance 1993).

At about the Oligocene-Miocene boundary (c. $25 \mathrm{Ma}$ ), subduction resumed along the eastern margin of New Zealand, marking the inception of the present boundary between the Indo-Australian and Pacific plates. The southwest-dipping trench-arc system was initially established in Northland. However, the history of its progression to the present position is still being debated (Kamp 1984; Brothers 1986; Ballance 1988; Kear 1994). Synchronous with this development was the formation of the Alpine Fault as a continuous transform through the New Zealand block, intersecting obliquely the earlier late Eocene to mid Oligocene rift system of western South Island (Kamp 1986b). The other tectonic events that are significant to this study and related to this change were: (1) obduction of nappes of the Northland Allochthon (the former passive margin wedge) between 24 and $22 \mathrm{Ma}$, along with the cbduction of the Tangihua/Matakaoa ophiolites (Ballance \& Spörli 1979; Hayward et al. 1989); and (2) the development of the inter-arc Waitemata Basin (Ballance 1974; Hayward 1993; Isaac et al. 1994).

At c. $15 \mathrm{Ma}$, the arc on the western side of the Waitemata Basin became extinct, and the basin fill was uplifted above sea level (Ballance et al. 1982). As the subduction system propagated south, so did the related volcanism. In the mid Miocene, a back-arc rift regime with rhyolitic volcanism was established on the Coromandel Peninsula (Fig. 1), as part of a northeast-trending Colville-Coromandel-Taranaki arc (Herzer 1995). From the late Pliocene to Present, the volcanic arc migrated to its present position in the Taupo Volcanic Zone.

\section{Waitemata Basin}

One of the immediate responses to renewed subduction at c $25 \mathrm{Ma}$ was the beginning of sedimentation in the long and narrow Waitemata Basin depocentre (present dimensions: c $130 \times 60 \mathrm{~km}$; Fig. 1). Deposition occurred between two parallel and northwest-trending coeval calc-alkaline arcs, considered to be situated above a west-southwest-dipping subduction system (Ballance 1974, 1976, in press; Hayward 1993) (Fig. 2).
Surrounding and underlying the basin are the late Paleozoic-Tertiary sedimentary rocks of the Waipapa GroupMurihiku Supergroup, the Northland Allochthon, and Te Kuiti Group. In the east the basin sequence onlaps the autochthonous, low-grade metamorphosed, PermianJurassic rocks of the accretionary complex known as the Waipapa Group. To the northwest, and in the centre of the basin, strata rest unconformably on strongly deformed and displaced deep-marine rocks of the Northland Allochthon. The basin is flanked to the north and south by uplifted basement blocks, over which thinner sequences of sandstone, mudstone, and a few turbidite beds accumulated (Ballance 1974). Both blocks consist of autochthonous Oligocene Te Kuiti Group carbonate and sandstone overlying the Mesozoic Murihiku and Waipapa rocks. Summary of the potential source rocks to the basin is given in Table 1

The main part of the Waitemata Basin fill is an interbedded turbidite sandstone and pelagic siltstone sequence deposited at bathyal depths during the Otaian Stage c. 23-19 Ma (Ballance 1974; Hayward 1979). Interbedded with these sequences are thicker volcaniclastic mass-flow units of possibly lahar/debris avalanche origin (e.g., Parnell Grit beds; Ballance \& Gregory 1991). Paleocurrent directions indicate that most of the sediment supply was from the northwest (Ballance 1974).

Internal stratigraphy and correlation within the basin is poorly established due to the lack of marker units and the complexity of the deformation (Ballance 1974; Spörli 1989a). However, there is a general regional tilt and younging towards the west (Ballance 1974; Hayward 1979). The deposits generally are poorly consolidated and commonly gently dipping or flat lying, but zones of intense folding and faulting occur locally displaying syndepositional and post-depositional deformation (Spörli 1989a).

Total thickness of the sedimentary package in the basin is unknown. The youngest preserved sediments in the far west are Altonian in age (c. $17 \mathrm{Ma}$ ), and any record of the more recent geological history is missing over most of the basin. However, in the southernmost part of the basin, the Waitemata sediments are unconformably overlain by the late Pliocene Kaawa Formation (inner shelf-shoreface facies, Isaac et al. 1994), bracketing the earliest denudation as prelate Pliocene.

Zeolites are commonly found as the principal authigenic minerals of volcanogenic sediments and have been used as a record of low-temperature burial diagenesis (Coombs et al. 1959; Ijima 1988). The sediments in the Waitemata Basin are in part volcaniclastic and contain zeolites. Sameshima (1978) related zeolite formation to hydrothermal activity in the basin, and Davidson \& Black (1994) concluded that zeolitisation was the product of diagenesis at temperatures not exceeding $100^{\circ} \mathrm{C}$

\section{THERMAL INDICATORS}

\section{Organic maturity}

Optical reflectance of the vitrinite maceral group was measured to determine the level of maturation. Using the relationship between VR, time, and temperature, based on the kinetic model of Burnham \& Sweeney (1989), we estimated maximum paleotemperatures. 


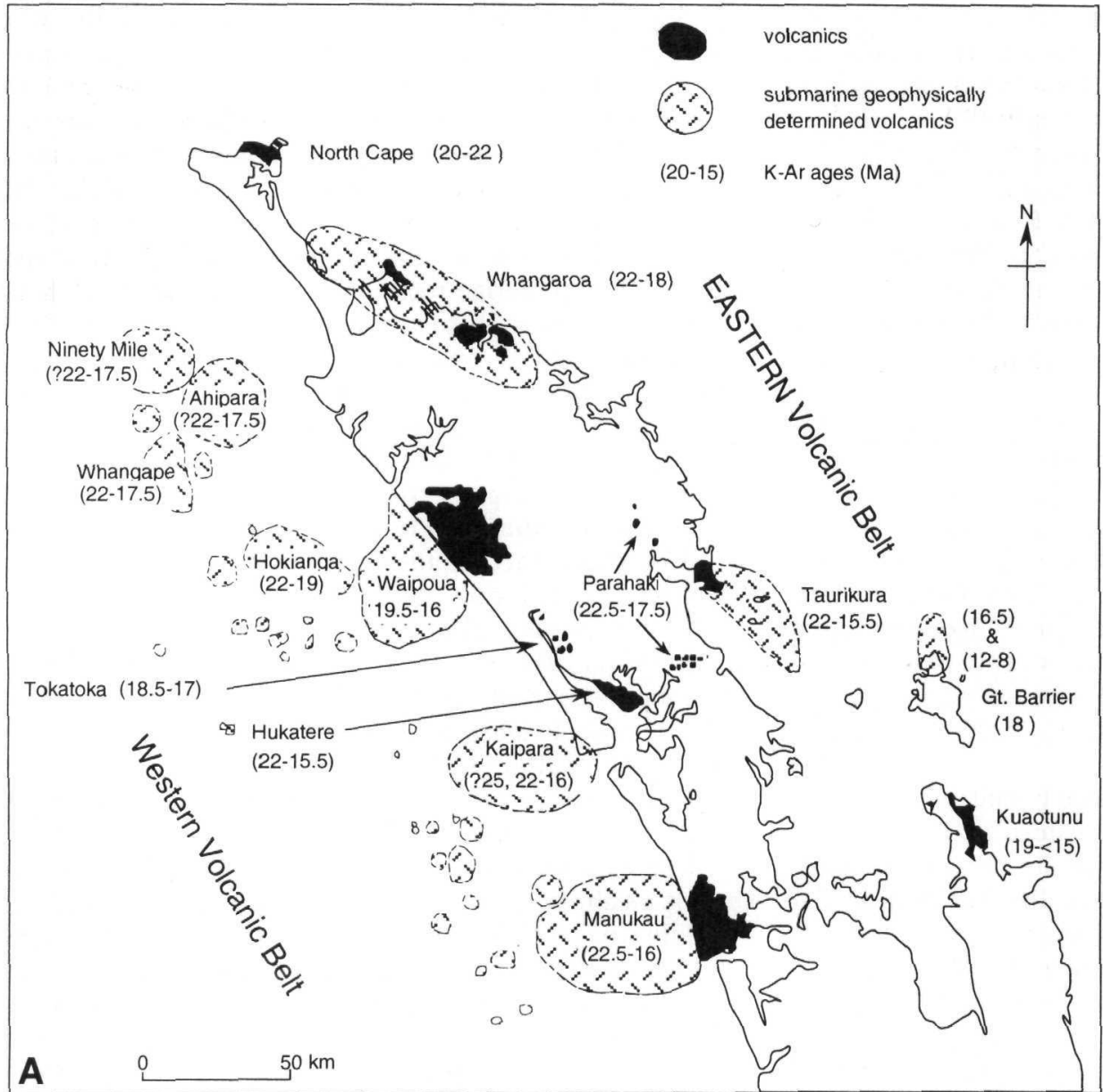

West
Fig. 2 A, Map showing the distribution of early Miocene arctype volcanic complexes with $\mathrm{K}-\mathrm{Ar}$ ages (modified after Hayward 1993 and Herzer 1995). The volcanic centres are part of the Eastern and Western Volcanic Belts. The $\mathrm{K}-\mathrm{Ar}$ ages of the volcanics are coeval with the youngest population of AFT ages determined from the basin, indicating a significant proportion of sedimentary fill of the basin was derived from the contemporaneous volcanism. K-Ar age of North Cape from Smith et al. (1989); Gt Barrier from Kear (1994); Poor Knights Island, Mokohinau Islands, and Gt Barrier Island from Nicholson (1995). Poor Knights and Mokohinau Islands are c. 88 and $28 \mathrm{~km}$, respectively, northwest of $\mathrm{Gt}$ Barrier Island. B, Schematic section showing the geological setting of the Waitemata Basin. The maximum sediment thickness in the basin is c. $1 \mathrm{~km}$ (Ballance 1974).

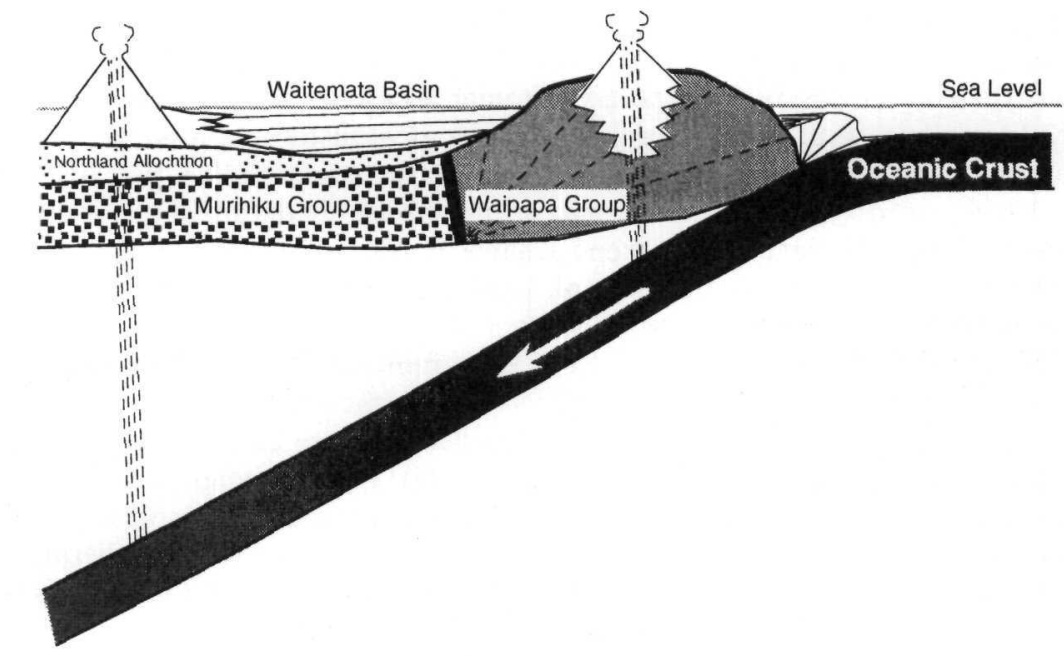

Not to scale

\section{Results}

Eight samples from concentrated lenses of organic matter in outcrop were collected for analysis on a reconnaissance basis (Fig. 3). Results show some variation in reflectance, but the mean random reflectance values do not exceed $0.26 \%$, indicating that the organic matter is immature. As the stratigraphic positions of the individual samples are unknown due to the lack of marker horizons and complex deformation (Spörli 1989a), it is difficult to know whether minor variations in reflectance are due to differences in position in a stratigraphic column and hence in depth of burial. The important inference that can be deduced from the results is that the basin has not been buried deeply before exposure of the present surface. Maximum paleo- 
Fig. 3 Sample locations and measured VR values. Reflectances were measured with a Leitz MPV2 microscope photometer at the Geology Department, The University of Auckland. The photometer was calibrated before each sample was analysed using a standard (synthetic sapphire Ro $=0.545 \%$ ). All the measurements on samples and on standards were done in immersion oil of $\mathrm{Ne}=$ 1.5180 .

\begin{tabular}{llll}
\hline Manukau Harbour & $\begin{array}{c}\text { Number of } \\
\text { measurements }\end{array}$ & Ro \% & Std. Dev. \\
(1) Granny Bay & 91 & 0.22 & 0.04 \\
(2) Wesley Bay & 51 & 0.17 & 0.02 \\
(3) Green Bay & 99 & 0.26 & 0.03 \\
(4) Paturroa Bay & 42 & 0.21 & 0.05 \\
(5) Mill Bay & 93 & 0.25 & 0.04 \\
Waitemata Harbour & & & \\
(6) Ladies Bay & 82 & 0.18 & 0.03 \\
(7) St. Heliers Bay & 70 & 0.17 & 0.02 \\
Dairy Flat & & & \\
(8) Jeff Road & 77 & 0.25 & 0.04
\end{tabular}

temperatures of $<30^{\circ} \mathrm{C}$ are indicated by the VR results (Burnham \& Sweeney 1989).

This conclusion is particularly significant in terms of applying fission track analysis for provenance studies. Exposure to such low paleotemperatures would not anneal tission tracks in apatites, and measured fission track ages would therefore provide an undisturbed record of the AFT age of the source areas.

\section{Apatite fission track analysis}

Sensitivity of AFT analysis to temperatures within a window of $60-110^{\circ} \mathrm{C}$ does not limit its application to rocks exposed only to this range. It can be successfully applied to sedimentary rocks which remained at $<60^{\circ} \mathrm{C}$ to determine their provenance. In such cases, apatite would preserve the detrital ages and retain the inherited thermal signature of the source terrane. The organic maturity study from outcrop

Table 1 Summary of potential source rocks to the Waitemata Basin.

Potential source rocks Description

Waipapa Group

Northland Allochthon

Te Kuiti Group

Contemporaneous volcanism
The Permian to late Jurassic Waipapa Group consists of assemblages of tectonically imbricated terrigenous sediments and slices of ocean floor (cherts, argillites, and spilitic basalts) emplaced during the accretion stage (Spörli 1989b). Three phases of deformation have been recognised within the Waipapa Group rocks (Spörli 1978). The first two phases involve imbrication and folding of strata, and formation of mélange zones that are associated with, or predate, the Early Cretaceous Rangitata Orogeny. However, the third phase, of unknown age, produced open folding on steeply plunging axes. The distribution of metamorphic mineral zones suggests that there is a general increase in metamorphic grade from zeolite facies minerals dominant in the northeast to pumpellyiteactinolite facies in the southwest (Black 1989; Jennings 1989). The chemistry of minerals and mineral phase relationships indicate peak metamorphic conditions were achieved at $P \approx 3 \mathrm{kbar}, T \approx 250^{\circ} \mathrm{C}$ (Black et al. 1993) and metamorphism was largely syntectonic (Black 1989). However, continued deformation beyond the time of peak metamorphism is indicated by the presence of a late vein assemblage with lower metamorphic grade than the host rocks (Black 1989).

The Northland Allochthon comprises the thick, Cretaceous-Paleogene sequence of rocks that form the north and northwestern boundary and underlie much of the Waitemata Basin. The allochthon consists of obducted, stacked nappes of predominantly deep-marine strata and incorporated adjacent seafloor known as the Tangihua/Matakaoa ophiolites (Isaac et al. 1994). Ballance (1993) described them as a fining-upward passive margin sequence, deposited following the late Mesozoic cessation of Gondwana subduction and terrane accretion. There is general agreement that the Northland Allochthon was derived from the northeast and was emplaced by gravity sliding onto the autochthonous Te Kuiti Group and the underlying Waipapa Group basement. It interfingers with basal Waitemata strata.

These Eocene-Oligocene rocks of Te Kuiti Group are up to $300 \mathrm{~m}$ thick and rest unconformably on Mesozoic basement. The lower part of the group comprises thin packages of limestone interfingered with marine to marginal marine siliciclastic units, and the upper part shows lateral compositional variation from limestone to thick calcareous siltstone (Nelson 1978; White \& Waterhouse 1993). The Te Kuiti Group was deposited during a period of relative tectonic quiescence and regional marine transgression before the onset of Neogene orogenesis.

With the inception of subduction during the late Oligocene, two parallel and co-eval volcanic arcs developed above the southwesterly dipping subduction zone (Brothers 1974; Ballance 1974, 1976, 1988; Kear 1994). Petrological and geochemical evidence indicates calc-alkaline affinities (Wright \& Black 1981; Smith et al. 1989). Lava types range from basaltic to rhyolitic, the western belt being generally more mafic than the eastern (Smith et al. 1989). The two northwest-trending volcanic belts, now $20-80 \mathrm{~km}$ apart (Fig. 2), are located onshore and offshore on either side of the Northland Peninsula (Hayward 1993; Herzer 1995). The biostratigraphic and K-Ar age data (Smith et al. 1989; Hayward 1993) indicate that volcanism took place between c. 27 and c. $16 \mathrm{Ma}$, synchronous with subsidence in the Waitemata Basin. 


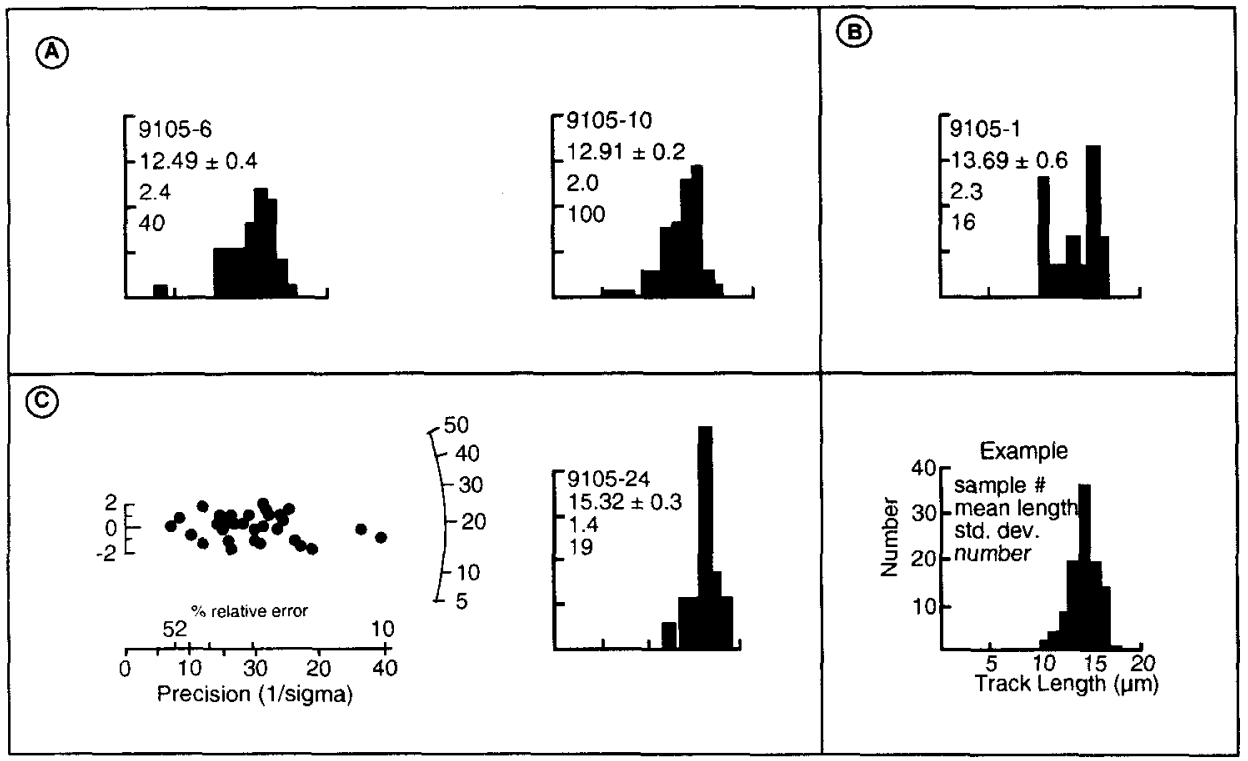

Fig. 4 AFT parameters for samples (A) 9105-6, 9105-10, (B 9105-1, (C) 9105-24. Track lengt distributions normalised to 10 . tracks for sample.

samples indicates that the basinal sediments were never heated above $60^{\circ} \mathrm{C}$. The individual grain ages can therefore be matched with grain ages from possible sediment source regions.

\section{Mixture modelling}

If the measured single-grain ages from a sample are detrital ages, they are often composed of multiple populations derived from different source areas that have contributed to the sedimentary mix. For example, a volcanogenic sandstone may contain apatites from a contemporaneous volcanic source, plus apatites from older sedimentary or igneous sources. The proportion of single-grain ages belonging to any one population may vary in a sample, perhaps indicating fluctuation in supply of sediments from one source or a change in source area, or simply the relative abundance of apatite-bearing rocks within various source terranes.

In order to resolve a mixture of detrital ages from a given dataset into a number of significant populations, a statistical approach known as "mixture modelling" has been used. This method has been described by Sambridge \& Compston (1994). This approach is equally useful for defining distinct components of apatite or zircon ages in partially annealed samples. In such samples the degree of annealing of fission tracks in each grain depends on the inherited variation in chemistry of the apatite/zircon, leading to a wide spread in single grain ages. The youngest population identified provides an estimate of the maximum time at which cooling occurred from maximum temperatures.

\section{Sample collection and processing}

AFT analysis has been performed on 31 sandstone samples from the Waitemata Basin and the possible basement source rocks (Table 2). Efforts were made to date at least 40 grains in each sample if sufficient datable grains were available. Ages for 1087 grains were obtained, of which 961 were from detrital apatites in the basin and the rest from basement rocks. Confined track lengths were also measured in some samples. In addition, zircon fission track (ZFT) ages from Waipapa
Group rocks were measured on the same samples from which apatite ages were obtained. The fission track data have been divided into two groups. The first group is from the basin and the second from the potential source rocks.

\section{Fission track results from the Waitemata Basin}

The Waitemata Basin has been divided arbitrarily into four regions for interpretation - the southern, central, northwes: and northeast regions (Fig. 1). This was done to test whether significant differences in provenance could be detected for different sub-regions of the basin, and to ensure that ary fine structure in the data was not obscured. AFT results are given in Table 2 . All samples yielded ages older than or equal to the depositional ages of the respective formations, signifying no post-depositional annealing. The low probability in the $\chi^{2}$ test for single grain ages indicates a mixture of age populations (Table 2).

\section{Southern region}

Confined track lengths were measured from only tw 0 samples (9105-6 and 9105-10; Fig. 1). Mean track lengths are $12.49 \pm 0.4 \mu \mathrm{m}$ and $12.91 \pm 0.2 \mu \mathrm{m}$, respectively (Fig. 4A). The distribution of track length in both sampl is unimodal but negatively skewed due to the presence of a few short tracks $<10 \mu \mathrm{m}$. The modal peaks in both samples are between 13 and $14 \mu \mathrm{m}$, suggesting that the majority if the tracks were formed at low temperatures.

By applying the mixture modelling method (Sambridte \& Compston 1994), the spread in individual grain ages indicates that they were almost certainly derived from sour areas of more than one age (Fig. 5). Modelling the data as two populations, the age of the youngest component (c. 21 $\pm 1 \mathrm{Ma}$ ) falls within the range of the $\mathrm{K}-\mathrm{Ar}$ ages $(27-16 \mathrm{Ma}$ ) of the volcanics (Smith et al. 1989; Hayward 1993), which implies that an appreciable quantity of sediment was derived from the then active volcanic arcs.

The age of the oldest component of the two-population model is $81 \pm 2 \mathrm{Ma}$ (Fig. $5 \mathrm{~A}$ ), which is concordant with the youngest apatite cooling age obtained from the Waipapa 
Table 2 Fission track analytical results.

\begin{tabular}{|c|c|c|c|c|c|c|c|c|c|c|c|c|c|}
\hline $\begin{array}{l}\text { Sample } \\
\text { no. }\end{array}$ & Locality & $\begin{array}{l}\text { Formation } \\
\text { or group }\end{array}$ & $\begin{array}{c}\text { Grid } \\
\text { reference }\end{array}$ & $\begin{array}{l}\text { No, of } \\
\text { grains }\end{array}$ & $\begin{array}{c}\text { Standard track } \\
\text { density } \\
\left(\times 10^{6} \mathrm{~cm}^{-2}\right)\end{array}$ & $\begin{array}{c}\text { Fossil track } \\
\text { density } \\
\left(\times 10^{5} \mathrm{~cm}^{-2}\right)\end{array}$ & $\begin{array}{c}\text { Induced } \\
\text { track density } \\
\left(\times 10^{5} \mathrm{~cm}^{-2}\right)\end{array}$ & $\begin{array}{l}\text { Uranium } \\
\text { content } \\
(\mathrm{ppm})\end{array}$ & $\begin{array}{c}\text { Variation } \\
(\%)\end{array}$ & $\begin{array}{c}\text { Chi square } \\
\text { probability } \\
(\%)\end{array}$ & $\begin{array}{l}\text { Fission } \\
\text { track age* } \\
\text { (Ma) }\end{array}$ & $\begin{array}{l}\text { Mean track } \\
\text { length } \\
(\mu \mathrm{m})\end{array}$ & $\begin{array}{c}\text { SD } \\
(\mu \mathrm{m})\end{array}$ \\
\hline \multicolumn{14}{|c|}{ Waitemata Basin (early Miocene) } \\
\hline $9105-1$ & West Tamaki Head & Parnell Grit & R11/778824 & 38 & $1.340(11483)$ & $0.866(197)$ & $5.821(1321)$ & 5.3 & 94 & 0 & $38 \pm 7$ & $13.69 \pm 0.6(16)$ & 2.3 \\
\hline $9105-2$ & Ladies Bay & East Coast Bays Fmn & R11/763823 & 30 & $1.345(11483)$ & $3.992(475)$ & $11.18(1330)$ & 10.2 & 40 & 0 & $73 \pm 8$ & - & - \\
\hline $9105-3$ & Bastion Point & East Coast Bays Fmn & R11/733824 & 38 & $1.357(11483)$ & $1.860(310)$ & $5.743(957)$ & 5.2 & 15 & 22 & $78 \pm 5$ & - & - \\
\hline $9105-4$ & Hobson Bay & East Coast Bays Fmn & R11/725804 & 22 & $1.366(11483)$ & $2.503(382)$ & $9.599(1465)$ & 8.6 & 59 & 0 & $\mathbf{5 0} \pm 8$ & - & - \\
\hline $9105-5$ & Music Point & East Coast Bays Fmn & R11/804807 & 30 & $1.374(11483)$ & $3.829(507)$ & $14.76(1954)$ & 13.2 & 31 & 0 & $62 \pm 5$ & - & - \\
\hline $9105-6$ & Foster Bay & Cornwallis Facies & $\mathrm{R} 11 / 507652$ & 40 & $1.383(11483)$ & $4.421(783)$ & $11.91(2110)$ & 10.6 & 30 & 0 & $79 \pm 6$ & $12.49 \pm 0.4(40)$ & 2.4 \\
\hline $9105-8$ & Mill Bay & Blockhouse Bay Fmn & $\mathrm{R} 11 / 535665$ & 40 & $1.392(11483)$ & $2.744(534)$ & $8.772(1707)$ & 7.8 & 54 & 0 & $64 \pm 7$ & - & - \\
\hline $9105-10$ & Wood Bays & Blockhouse Bay Fmn & $\mathrm{R} 11 / 590718$ & 40 & $1.409(11483)$ & $6.482(751)$ & $17.42(2018)$ & 15.2 & 40 & 0 & $83 \pm 7$ & $12.91 \pm 0.2(100)$ & 1.9 \\
\hline $9105-12$ & Granny Bay & East Coast Bays Fmn & $\mathrm{R} 11 / 670730$ & 29 & $1.426(11483)$ & $4.395(644)$ & $13.08(1916)$ & 11.3 & 29 & 0 & $79 \pm 6$ & - & - \\
\hline $9105-13$ & Takapuna Beach & East Coast Bays Fmn & $\mathrm{R} 11 / 705875$ & 40 & $1.443(11483)$ & $3.104(728)$ & $10.49(2459)$ & 8.9 & 42 & 0 & $69 \pm 6$ & - & - \\
\hline $9105-14$ & Hatfield Beach & East Coast Bays Fmn & R10/620135 & 40 & $1.443(11483)$ & $4.624(835)$ & 14.59 (2634) & 12.4 & 34 & 0 & $76 \pm 7$ & - & - \\
\hline $9105-15$ & Riverhead & Riverhead $\mathrm{Cg}$ & R10/530929 & 40 & $1.452(11483)$ & $1.883(294)$ & $10.97(1712)$ & 9.3 & 65 & 0 & $40 \pm 5$ & - & - \\
\hline $9105-17$ & Norton Quarry & Albany $\mathrm{Cg}$ & $\mathrm{R} 10 / 544979$ & 40 & $1.469(11483)$ & $5.284(1102)$ & $16.27(3393)$ & 13.6 & 33 & 0 & $78 \pm 6$ & - & - \\
\hline $9105-18$ & Phuehue Bridge & Pakiri Facies & $\mathrm{R} 09 / 586256$ & 35 & $1.477(11483)$ & $6.250(876)$ & $18.02(2525)$ & 15.0 & 72 & 0 & $70 \pm 10$ & - & - \\
\hline 9105-19 & Leigh Marine Lab. & Pakiri Facies & R09/718464 & 41 & $1.486(11483)$ & $4.078(758)$ & $12.86(2390)$ & 10.6 & 27 & 0 & $78 \pm 5$ & $12.64 \pm 0.3(58)$ & 2.0 \\
\hline $9105-22$ & Highway 16 & Pakiri Facies & Q09/392286 & 45 & $1.387(7681)$ & $2.729(875)$ & $8.330(2671)$ & 7.4 & 86 & 0 & $49 \pm 7$ & - & \\
\hline $9105-24$ & Puketotara Peninsula & Motuouhi Fmn & $\mathrm{Q} 09 / 248483$ & 35 & $1.410(7681)$ & $1.101(290)$ & $14.27(3758)$ & 12.4 & 11 & 36 & $20 \pm 1$ & $15.32 \pm 0.3(19)$ & 1.4 \\
\hline $9105-25$ & Kaipara Harbour & Motuouhi Fmn & Q $09 / 257489$ & 40 & $1.422(7681)$ & $3.856(1364)$ & $11.49(4063)$ & 9.9 & 47 & 0 & $79 \pm 7$ & - & - \\
\hline $9105-26$ & Timber Bay & Timber Bay Fmn & Q09/273497 & 40 & $1.434(7681)$ & $4.797(893)$ & $14.43(2686)$ & 12.4 & 46 & 0 & $72 \pm 6$ & - & - \\
\hline $9105-27$ & Ngamotu Locality & Timber Bay Fmn & $\mathrm{Q} 09 / 287487$ & 40 & $1.446(7681)$ & $3.225(566)$ & $10.50(1843)$ & 8.9 & 37 & 0 & $74 \pm 6$ & $12.16 \pm 0.4(41)$ & 2.44 \\
\hline $9105-28$ & Bream Tail & Ngatoka Fmn & R08/528719 & 40 & $1.458(7681)$ & $4.038(867)$ & $14.94(3208)$ & 12.6 & 67 & 0 & $59 \pm 7$ & - & - \\
\hline $9105-29$ & Bream Tail & Ruarangi Fmn & $\mathrm{R} 08 / 510716$ & 14 & $1.470(7681)$ & $2.015 \quad(89)$ & $19.54 \quad(863)$ & 16.4 & 29 & 5 & $27 \pm 3$ & - & - \\
\hline $9105-30$ & Port Waikato & Waikawau Sst & $\mathrm{R} 13 / 646082$ & 40 & $1.481(7681)$ & $1.767(291)$ & $7.163(1180)$ & 5.9 & 88 & 0 & $59 \pm 9$ & - & \\
\hline $9105-31$ & Omana Beach & Kawan Fmn & S11/913786 & 29 & $1.493(7681)$ & $3.386(423)$ & $10.27(1283)$ & 8.5 & 60 & 0 & $66 \pm 9$ & - & - \\
\hline $9105-33$ & Mercer & Amokura Fmn & S13/931279 & 28 & $1.517(7681)$ & $4.452(470)$ & $19.81(2091)$ & 16.1 & 36 & 0 & $65 \pm 6$ & - & - \\
\hline $9105-34$ & Mercer & Mercer Sst & $\mathrm{S} 12 / 918350$ & 27 & $1.529(7681)$ & $2.167(354)$ & $10.16(1659)$ & 8.2 & 44 & 0 & $60 \pm 7$ & - & - \\
\hline $9105-36$ & Hanua Gorge & East Coast Bays Fmn & Q12/R12/865567 & 40 & $1.552(7681)$ & $87.05 \quad(170)$ & $7.056(1378)$ & 5.6 & 58 & 0 & $33 \pm 4$ & - & - \\
\hline \multicolumn{14}{|c|}{ Waipapa Group (Permian-Jurassic) } \\
\hline $9105-32$ & Omana Beach & Waipapa Gp & S11/913786 & 34 & $1.505(7681)$ & $1.646(193)$ & $3.872(454)$ & 3.2 & 0 & 99 & $113 \pm 10$ & $15.77 \pm 0.6(5)$ & 1.4 \\
\hline $9105-32 Z$ & Omana Beach & Waipapa Gp & S11/913786 & 15 & $0.6674(2799)$ & 79.63 (1647) & $23.79 \quad(492)$ & 143 & 13 & 10 & $138 \pm 8$ & - & - \\
\hline $9105-35$ & Winstone Quarry & Waipapa Gp & Q12/R12/880564 & 40 & $1.541(7681)$ & $5.026(556)$ & 11.59 (1282) & 9.2 & 9 & 73 & $119 \pm 7$ & $14.34 \pm 0.2(62)$ & 1.5 \\
\hline $9105-35 Z$ & Winstone Quarry & Waipapa Gp & Q12/R12/880564 & 12 & $0.6718(2799)$ & $69.28(2639)$ & $14.75 \quad(562)$ & 86 & 16 & 1 & $191 \pm 13$ & - & - \\
\hline $9105-37$ & Tawharanui Reg. Park & Waipapa Gp & $\mathrm{R} 09 / 765356$ & 40 & $1.564(7681)$ & $2.948(285)$ & $9.680(936)$ & 7.6 & 2 & 85 & $84 \pm 6$ & $14.21 \pm 0.3(48)$ & 1.7 \\
\hline $9105-37 Z$ & Tawharanui Reg. Park & Waipapa Gp & $\mathrm{R} 09 / 765356$ & 11 & $0.6763(2799)$ & $90.66(1336)$ & $25.58 \quad(377)$ & 148 & 24 & 0 & $143 \pm 14$ & - & - \\
\hline \multicolumn{14}{|c|}{ Northland Allochthon (Late Cretace } \\
\hline $9105-21$ & Maungturoto Peninsula & Northland Allochthon & Q08:252562 & 12 & $1.375(7681)$ & $9.685(410)$ & $9.685(410)$ & 8.7 & 15 & 9 & $113 \pm 10$ & $11.63 \pm 0.6(8)$ & 1.7 \\
\hline
\end{tabular}

Methodology adopted for fission track analysis has been described by Green et al. (1989). Fission track data collected using external detector method (Gleadow 1981). Neutron irradiations were carried out at HIFAR Research Reactor, Lucas Heights, Australia.

Brackets show number of tracks counted or measured. Standard and induced track densities measured on mica external detectors $(\mathrm{g}=0.5)$, and fossil track densities on internal mica surfaces. Ages calculated by A. Raza using the zeta $=357 \pm 5$ for apatite and $125 \pm 3$ for zircon, for dosimeter glasses SRM- 612 and CN 1 , respectively.

*Central age; †One sigma error used.

Sample number with letter " $\mathrm{Z}$ " is zircon fission track data.

All samples collected at sea level.

Fmn, Formation; Gp, Group; Cg, Conglomerate; Sst, Sandstone; Reg., Regional; Lab, Laboratory. 

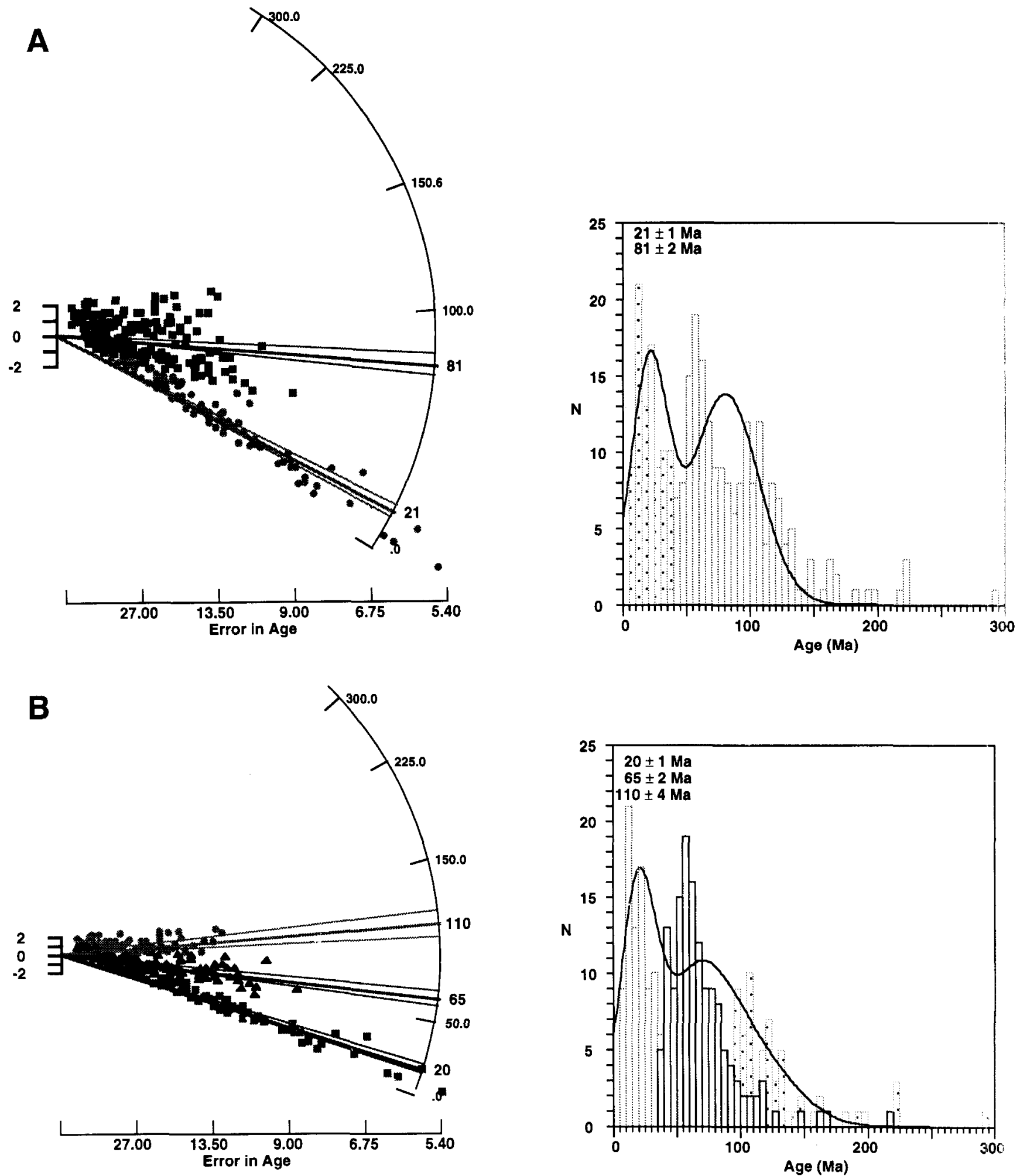

Fig. 5 Estimation of the maximum likelihood set of age populations and their mean ages using 313 apatite age measurements samples $9105-6,-8,-10,-12,-30,-31,-33,-34,-36$ in the southern region of the Waitemata Basin. Mean age of each population $w^{\prime}$ is determined assuming a Gaussian error and by applying the mixture modelling approach described by Sambridge \& Compston (1994). The racial plot graphically displays the age and associated error. The position on the $x^{\prime}$-axis records the uncertainty of individual age estimates. Each age has the same standard error on the $y^{\prime}$-axis (illustrated as $\pm 2 \sigma$ ). The value of any datum can be determined by extrapolating a line from the origin at the left of the plot through the $x, y$ co-ordinates to intercept the radial scale. The more distant the point plots from the origin, the higher the precision on the measurement. A, Estimation of mean ages $( \pm I \sigma)$ assuming two populations yielded c. $21 \pm 1$ and c. $81 \pm 2 \mathrm{Ma}$ ages, indicating contemporaneous volcanism and Waipapa Group rocks as provenances. B, Estimation of mean ages $( \pm 1 \sigma)$ assuming three populations yielded c. $20 \pm 1$, c. $65 \pm 2$, and c. $110 \pm 4$ Ma ages. The $20 \pm 1$ and $110 \pm 4$ Ma ages are the same as in (A) but the c. $65 \pm 2 \mathrm{Ma}$ age is derived from a source which is unknown (see discussion in text). 

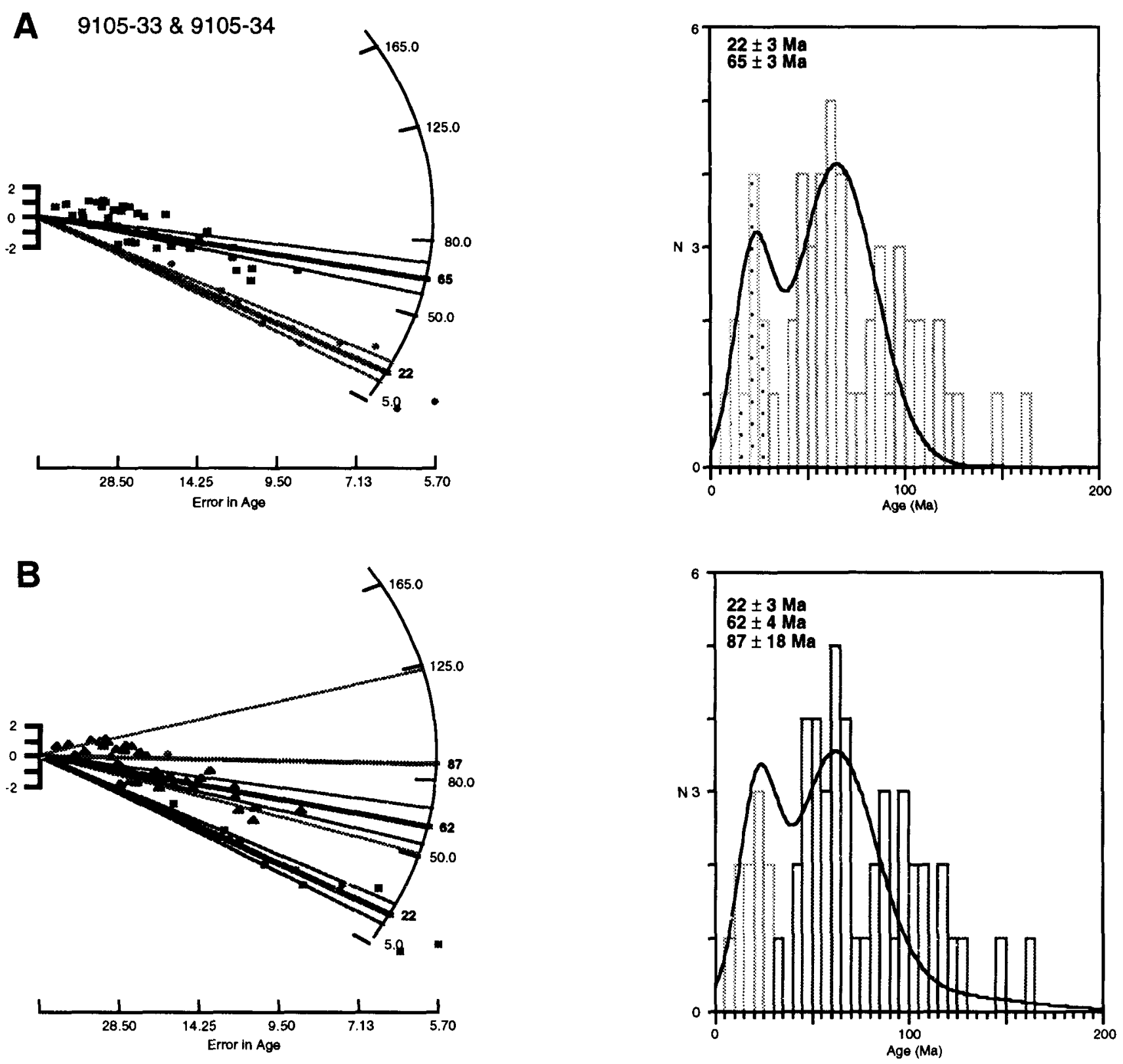

Fig. 6 Estimation of the maximum likelihood set of age populations and their mean ages using 55 apatite age measurements of camples $9105-33$ and 9105-34 from the southernmost part of the Waitemata Basin (notation as Fig. 5). A significant proportion of ingle-grain ages belong to the c. $65 \pm 3$ Ma population, which indicates a source that cooled during the latest Cretaceous and served as a Miocene sediment source. A, Two population model. B, Three population model.

Group samples ( $84 \pm 6 \mathrm{Ma}$ ). The Waipapa Group rocks may therefore have been a source of sediment. This result is compatible with earlier findings (Ballance 1974; Hayward \& Smale 1992) that suggest Waipapa Group rocks have been one of the sources that supplied sediments to the basin, either directly or indirectly.

However, the mixture modelling suggests that the southern region data are better described by a mixture of three age populations (Fig. 5B). If the detrital apatite ages from this region are segregated modelling three populations, the previously determined population of c. $20 \mathrm{Ma}$ (within the limits of cooling ages) was recovered. The remaining older ages were split into two new and significantly different populations of $65 \pm 2 \mathrm{Ma}$ and $110 \pm 4 \mathrm{Ma}$ (Fig. 5B). Previously, these ages collectively formed the oldest component $(81 \mathrm{Ma})$ of the two-population model. Close inspection of the single-grain ages reveals that the majority of ages for two of the samples, 9105-33 and 9105-34, are from this intermediate population of $65 \pm 3 \mathrm{Ma}$ (Fig. 6). Both samples are from the southern part of the basin, and belong to the Amokura Formation and Mercer Sandstone. The sandstone from both units, being non-calcareous, ungraded and thickly bedded, lithic to quartzose in nature (Ballance 1976), is lithologically distinct from the central region flysch facies. These units were perhaps derived from a source that subsequently was completely eroded, but which cooled during the Late Cretaceous or early Tertiary.

The oldest population recovered from the three agecomponent model ( $110 \pm 4 \mathrm{Ma})$ is concordant with both the older samples from the Waipapa Group rocks (117 $\pm 7 \mathrm{Ma}$, 

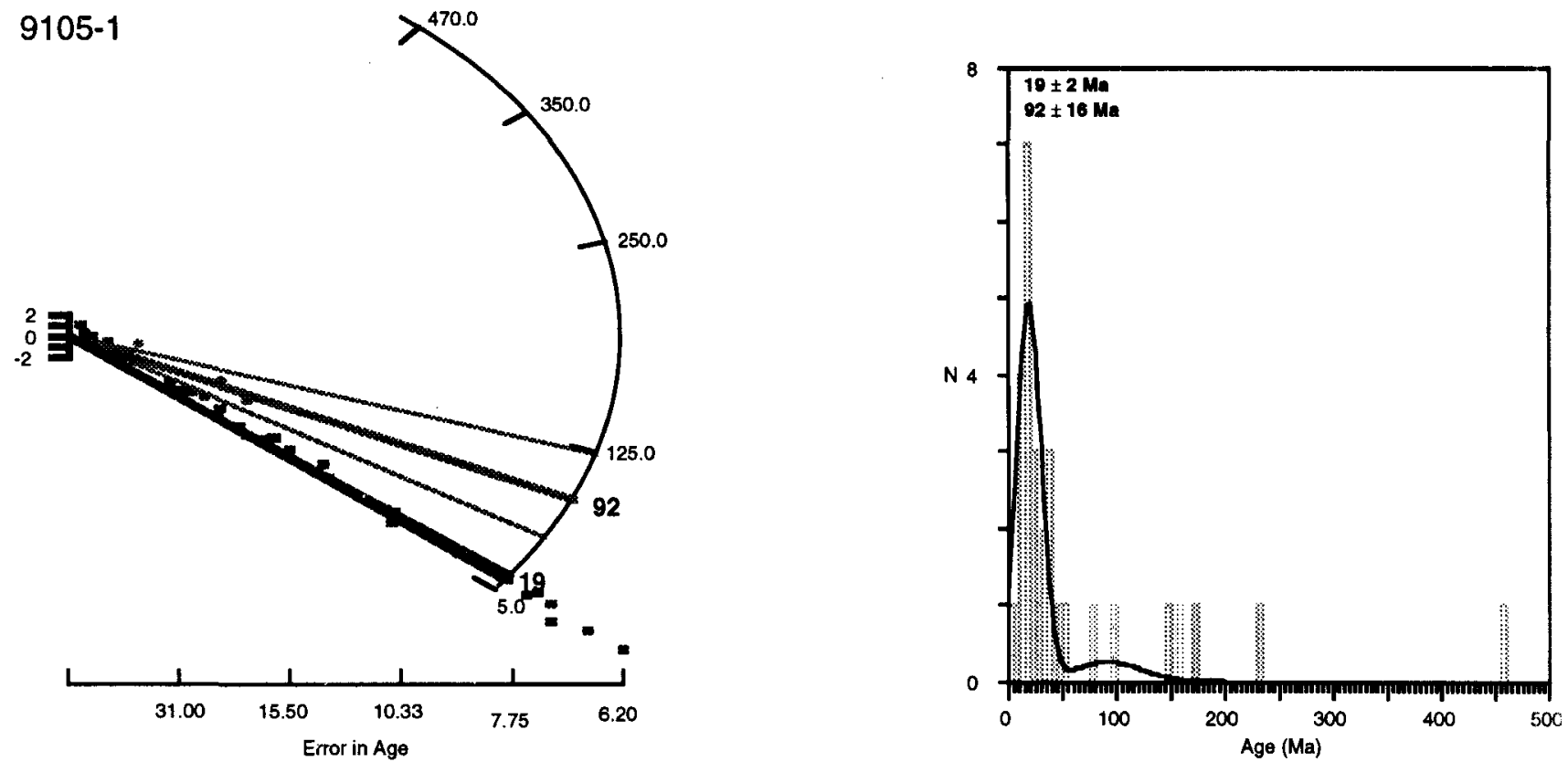

Fig. 7 Estimation of the maximum likelihood set of age populations and their mean ages using 38 apatite age measurements of sampls: 9105-1 from the Parnell Grit bed outcrop at West Tamaki Head (notation as for Fig. 5). The radial plot and histogram shows the presence of two distinct populations of c. $19 \pm 2$ and c. $92 \pm 16 \mathrm{Ma}$ (see text for detail).

weighted mean) and the single age from the Northland Allochthon $(113 \pm 10 \mathrm{Ma})$. Either of these regions could have been a source, and we are unable to differentiate between the two on the basis of the fission track data alone.

\section{Central region}

The central region comprising the East Coast Bays Formation is located between Auckland and Hatfield Beach (Fig. 1). Sample 9105-1 was collected from a Parnell Grit bed, a potential marker horizon, exposed at West Tamaki Head along Waitemata Harbour. The distribution of singlegrain ages in this sample is composed of two populations (Fig. 7). The majority ( $>85 \%)$ of the single-grain ages are from a young population with an estimated age of $19 \pm 2 \mathrm{Ma}$. This suggests that the Parnell Grit was derived mainly from the contemporaneous volcanic source. This inference is consistent with the lithology of the unit, which has been interpreted as representing submarine volcanic mudflows or lahars, with abundant lithic and crystal volcanic debris (Ballance 1974; Ballance \& Gregory 1991). Nonetheless, the presence of a less dominant and less precise population (estimated age $92 \pm 16 \mathrm{Ma}$ ) indicates that some of the sediments were derived from another source. Within the Parnell Grit beds, sedimentary debris of intrabasinal origin is abundant and includes large rafts of sandstone (Ballance 1974; Ballance \& Gregory 1991). Thus, this minor, older apatite component is most likely to have been sourced from Waipapa Group basement rocks and incorporated into the Parnell Grit flow by cannibalising of older Waitemata Basin deposits. The mean track length for this sample, of $13.69 \pm 0.6 \mu \mathrm{m}$, is fairly high (Fig. 4B). Fewer than the desired number of tracks were available for measurements, making it difficult to draw any firm conclusions, but the long mean track length indicates that apatites were derived from rapidly cooled sources (i.e., syn-volcanic material).
Modelling the combined individual grain ages of all samples from the central region as a two-component mixture indicates the existence of two statistically distinct populations (Fig. 8A). Estimated ages for these population, are $23 \pm 1$ and $84 \pm 2 \mathrm{Ma}$, again confirming contem. poraneous volcanism as a major sediment source. Altern. atively, segregating data from the central region into thre discrete populations gives estimated ages of $21 \pm 1,63 \pm 6$, and $97 \pm 3 \mathrm{Ma}$ (Fig. 8B). The youngest population of $21=$ $1 \mathrm{Ma}$ is essentially the same as that recovered previousl.; using a two-population division, and the three-populaticn model is statistically no better than the two-component model as indicated by their similar $\chi^{2}$ values (Table 3 ). The mixture modelling therefore indicates at least a twocomponent mixture of grain ages: one from a contemporaneous volcanic source and another with apatite ages giving a mean age of c. $84 \mathrm{Ma}$. There is no statistical justification for splitting this older group of ages further (Table 3 ), and the $84 \pm 2 \mathrm{Ma}$ mean age for this older group is similar to the younger age obtained from the Waipapt Group rocks (84 $\pm 6 \mathrm{Ma})$.

\section{Northwest region}

Sample 9105-24 (Fig. 1) is from the Motuouhi Formation on Puketotara Peninsula and yielded an apparent age, 20 t. $1 \mathrm{Ma}$, equal to its early Miocene stratigraphic age. The mean track length from this sample is $15.32 \pm 0.3 \mu \mathrm{m}$ (Fig. $4 \mathrm{C}$, with a unimodal symmetric track length distribution similar to the "undisturbed volcanic type" as described by Gleadow et al. (1986). This suggests that all of the apatites are from a contemporaneous volcanic source and have remained at temperatures $<60^{\circ} \mathrm{C}$ since deposition.

Mixture modelling of the combined individual grain ages of all the samples from the northwest region provides evidence for two discrete populations (Fig. 9A) with mean ages of $17 \pm 1 \mathrm{Ma}$, indicating contemporaneous volcanism, 

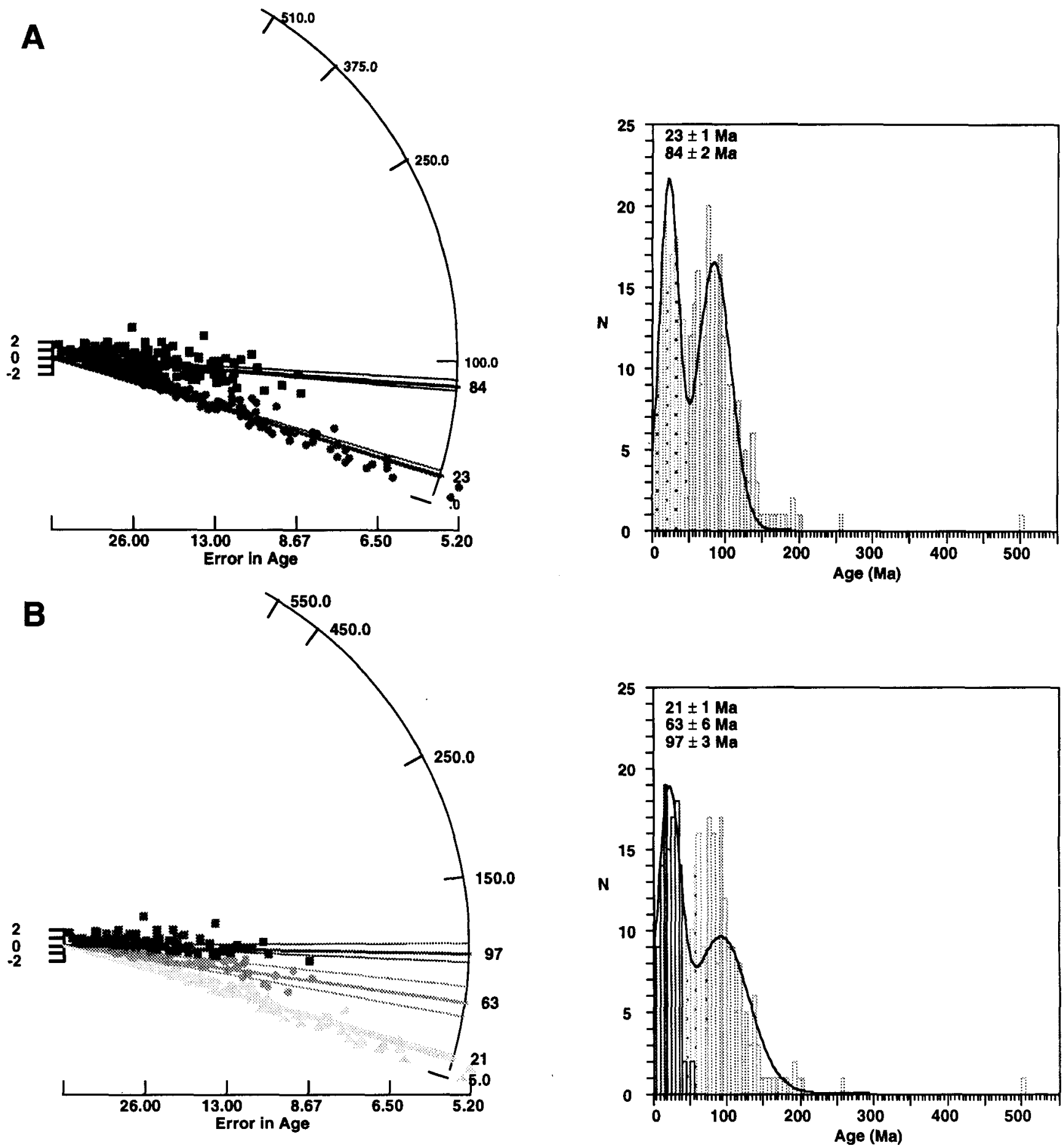

Fig. 8 Estimation of the maximum likelihood set of age populations and their mean ages using 353 apatite age measurements of samples $9105-1,-2,-3,-4,-5,-13,-14,-15,-17,-18$ in the central region of the Waitemata Basin. The display is the same as described for Fig. 5. A, Estimation of mean ages $( \pm 1 \sigma)$ assuming two populations yielded c. $23 \pm 1$ and c. $84 \pm 2$ Ma ages, indicating contemporaneous volcanism and Waipapa Group rocks as provenances. B, Estimation of mean ages $( \pm 1 \sigma)$ assuming three populations yielded c. $21 \pm 1$, c. $63 \pm 6$, and c. $97 \pm 3 \mathrm{Ma}$ ages (see text for detail).

and $88 \pm 2 \mathrm{Ma}$. Again, the estimated age for the older group of grains is similar to the younger cooling age obtained for the Waipapa Group rocks.

Mixture modelling of single-grain ages from the five samples assuming a three-component mixture yields ages of $17 \pm 1,77 \pm 3$, and $115 \pm 6 \mathrm{Ma}$ (Fig. 9B). The younger age is identical to the two-component model. The older populations cannot be statistically differentiated from each other on the radial plot and the $\chi^{2}$ values for the two- and three-component models are similar (Table 3 ). It is significant though that the range of grain ages within the older groups is similar to the age range measured for the Waipapa Group rocks $(84 \pm 6$ to $119 \pm 7 \mathrm{Ma})$ and is also similar to the single age measured for the Northland 
Allochthon $(113 \pm 10 \mathrm{Ma})$. At this stage we cannot differentiate two provenance regions on the basis of the fission track data.

\section{Northeast region}

Sample 9105-19 (Fig. 1) was collected just above the late Oligocene - early Miocene unconformity, from the basal Waitemata Group rocks, near Leigh Marine Laboratory. The distribution of single-grain ages is consistent with a twopopulation mixture with mean ages of $85 \pm 4$ and $28 \pm 6 \mathrm{Ma}$ (Fig. 10). Over $85 \%$ of the single-grain ages belong to the $85 \mathrm{Ma}$ population, confirming the earlier observation that most of the sediments for the basal part of the Waitemata Group were derived from Waipapa Group rocks (Ballance 1974; Ricketts et al. 1989). The younger population, although minor, is important as the $28 \pm 6 \mathrm{Ma}$ age is concordant with the oldest K-Ar ages (Smith et al. 1989; Hayward \& Smale 1992) from the volcanics. Although this age has a low precision, it helps constrain the initiation of subductionrelated volcanism.

Mixture modelling using a two-component model of the combined single-grain ages from the northeast region shows the same contemporaneous volcanic and Waipapa populations of $22 \pm 2$ and $85 \pm 3 \mathrm{Ma}$, respectively (Fig. 11A).

As with the other regions, separating the single-grain age data from the northeast region into three populations does not provide a statistically better mixture model (Fig. 11B). The youngest (19 $\pm 2 \mathrm{Ma})$ population and the range of grain ages for the older populations are comparable with the K-Ar ages of the Miocene volcanics and apatite cooling ages of the basement rocks, respectively.

\section{RESULTS FROM THE WAIPAPA GROUP}

Figure 12 shows the location of three samples, 9105-32, -35, and -37 for which both apatite and zircon fission track ages were measured. A greywacke sample collected near the Leigh Marine Laboratory did not produce any apatite. Samples analysed are from the pumpellyite - epidote actinolite metamorphic zone of the Waipapa Group (Black 1989). Analytical results obtained from AFT and ZFT analysis are given in Table 2.

\section{Apatite fission track results}

Samples $9105-32,-35$ and -37 yielded apatite ages of $113:$ : $10,119 \pm 6$, and $84 \pm 6 \mathrm{Ma}$, respectively. For all samples the measured AFT age has been significantly reduced when compared to the stratigraphic age (Permian-Jurassic) indicating severe annealing after deposition. The single-grai age distribution in each sample is consistent with a single age population, evident by the higher $(P) \chi^{2}$ values $(99,7$ and $85 \%$, respectively, Table 2 ).

The long mean-track lengths, low standard deviations and narrow, distinctly unimodal track length distribution: (Fig. 12) with a paucity of highly annealed tracks $(<10 \mu \mathrm{m}$ provide evidence of relatively rapid cooling from palec temperatures $\geq 110^{\circ} \mathrm{C}$. The apatite ages therefore sugges: that two distinct periods of cooling have been recorde within the basement: one during the Early Cretaceou: (119-113 Ma) and a later one during the mid Cretaceou (c. $84 \mathrm{Ma}$ ). At this stage, with only three sample: available, it is not possible to confirm the existence $c$ ) two separate events.

\section{Zircon fission track results}

The total annealing temperature for ZFT is higher than thel for apatite but is less well constrained, a range 0 : temperatures $\left(175-300^{\circ} \mathrm{C}\right.$ ) being cited in the literature (e.g Krishnaswami et al. 1974; Hurford 1986; Yamada et al. 1995 Green et al. 1996).

Samples $9105-32,-35$ and -37 were analysed by $\mathrm{ZFI}$ analysis yielding ages of $138 \pm 8,191 \pm 13$, and $143 \pm 14 \mathrm{Ma}$ respectively (Fig. 12; Table 2). These ages are older thar: apatite ages for the same samples. Mixture modelling of th: combined single-grain zircon ages indicates two discrete ag. populations (Fig. 13) of c. $112 \pm 7$ and $182 \pm 9 \mathrm{Ma}$. Th. younger population (c. $112 \pm 7 \mathrm{Ma}$ ) is significantly younge ? than the depositional age of the Waipapa Group (Permian Jurassic) and is concordant with the apatite cooling ages This suggests an episode of rapid cooling and denudation during the mid Cretaceous. The older zircon age population represents zircon grains with partially annealed tracks. The results from the ZFT analysis are consistent with the inferre degree of metamorphism $\left(P \approx 3 \mathrm{kbar} \approx 10 \mathrm{~km}, T \approx 250^{\circ} \mathrm{C}\right.$. Black et al. 1993).

Table 3 Summary of AFT population ages and statistical data.

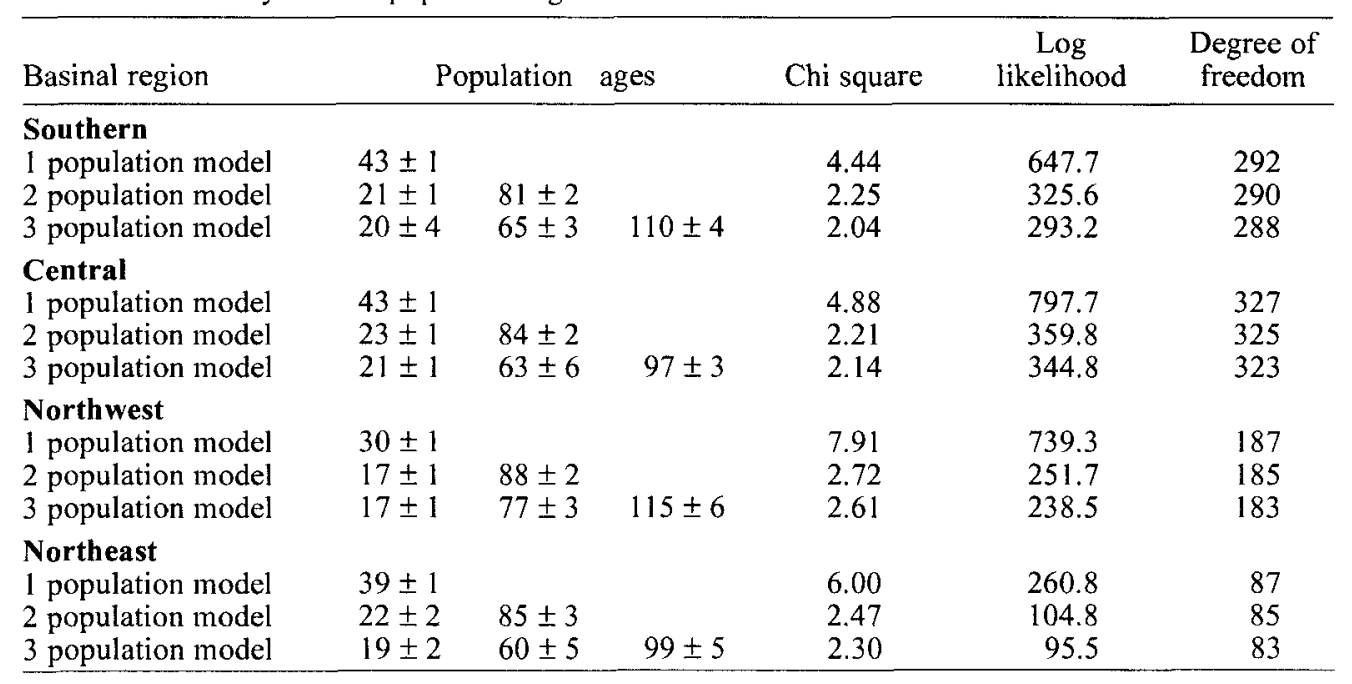



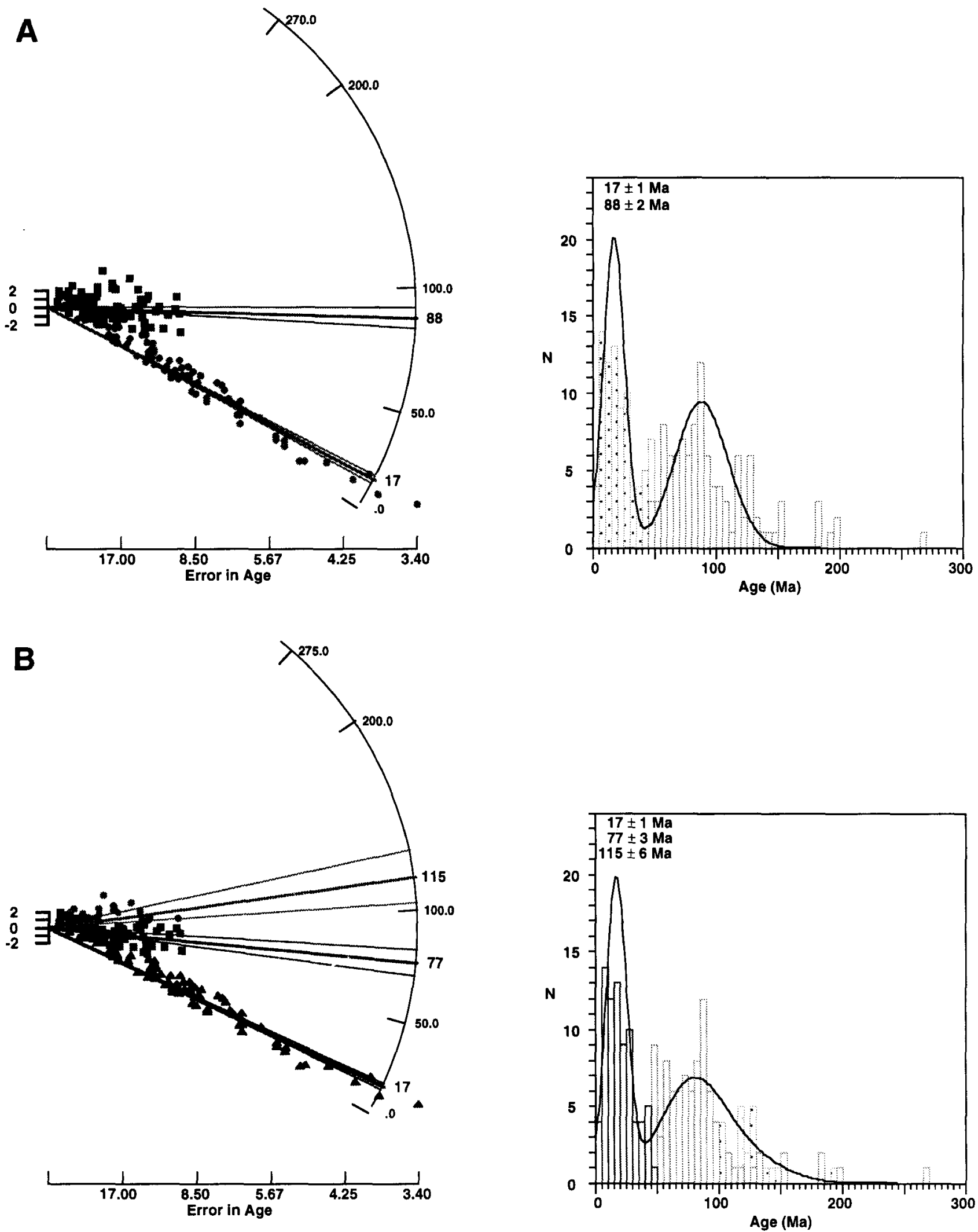

Fig. 9 Estimation of the maximum likelihood set of age populations and their mean ages using 200 apatite age measurements of samples $9105-22,-24,-25,-26,-27$ in the northwest region of the Waitemata Basin. The display is the same as described for Fig. 5. A, Estimation of mean ages $( \pm l \sigma)$ assuming two populations yielded c. $17 \pm 1$ and c. $88 \pm 2 \mathrm{Ma}$ ages, indicating contemporaneous volcanism and Waipapa Group rocks as provenances. B, Estimation of mean ages $( \pm 1 \sigma)$ assuming three populations yielded c. $17 \pm 1$, c. $77 \pm 3$, and c. $115 \pm 6 \mathrm{Ma}$ ages. The c. $17 \pm 1 \mathrm{Ma}$ age represents contemporaneous volcanism; however, c. $77 \pm 3$ and c. $115 \pm 6 \mathrm{Ma}$ ages are statistically the same and derived from Waipapa Group rocks. 

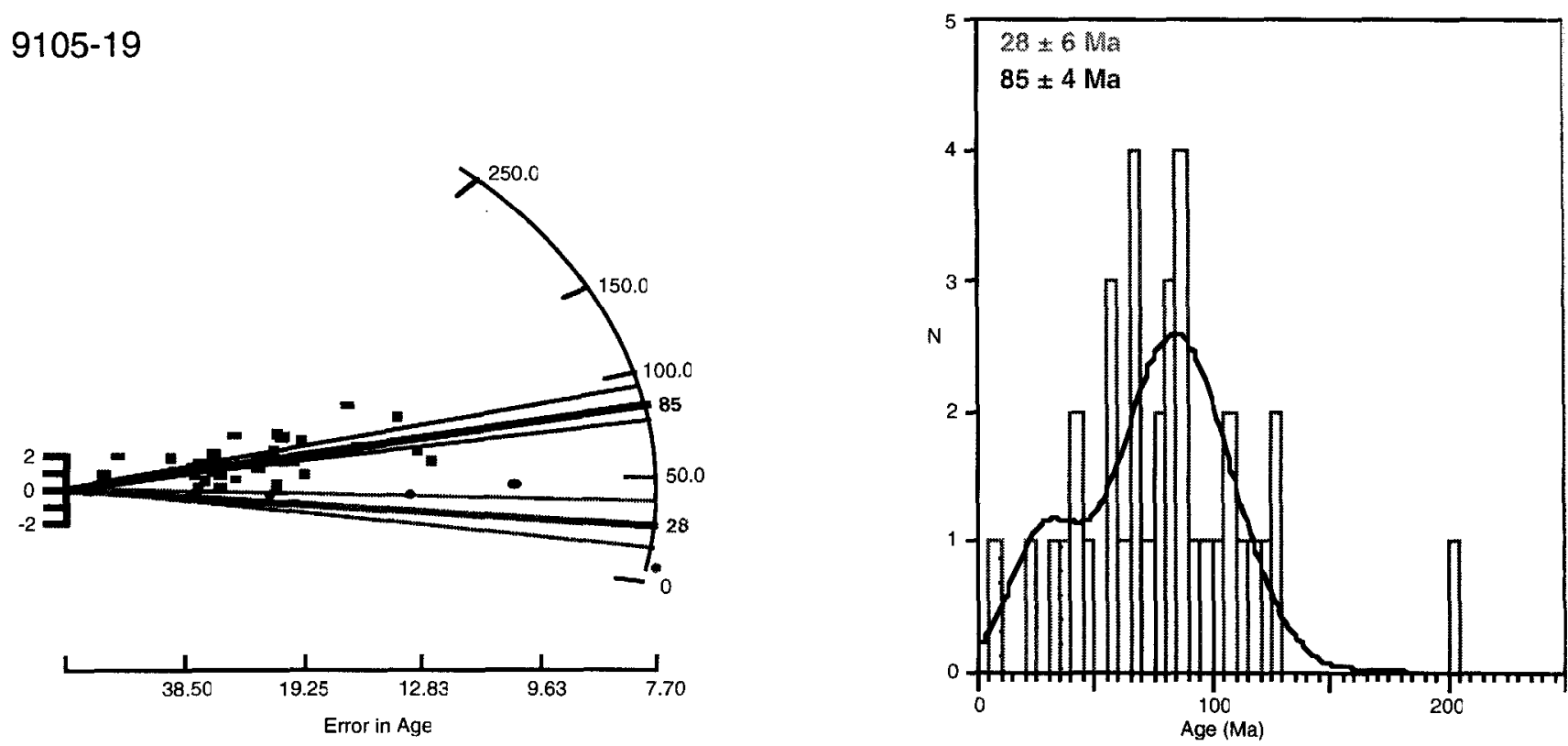

Fig. 10 Estimation of the maximum likelihood set of age populations and their mean ages using 41 apatite age measurements of $c$ sample (9105-19) in the northeast region of the Waitemata Basin. The display is the same as described for Fig. 5. This shows twc populations of age c. $28 \pm 6$ and c. $85 \pm 4$ Ma derived from contemporaneous volcanism and Waipapa Group rocks, respectively.

The concordance between the youngest zircon grains $(112 \pm 7 \mathrm{Ma})$ and the older AFT ages (119-113 Ma) implies rapid cooling at this time from c. $250^{\circ}$ to $<60^{\circ} \mathrm{C}$. Considering an average surface temperature of $10^{\circ} \mathrm{C}$, cooling from peak paleotemperatures took place at a rate of $180-36^{\circ} \mathrm{C} / \mathrm{Ma}(10$ $2 \mathrm{~mm} / \mathrm{yr}$ ), if this cooling occurred over an interval of c. $1-$ 5 m.y.

\section{RESULTS FROM THE NORTHLAND ALLOCHTHON}

Among the two samples (9105-21 and -23) collected from the Kaipara Harbour area for analysis, only one sample (9105-21) yielded apatite. The rocks exposed around this region belong to the Mangakahia and Motatau Complex of Late Cretaceous-Oligocene age (Hayward et al. 1989; Isaac et al. 1994). The AFT age of this sample is $113 \pm 10 \mathrm{Ma}$, which is older than the depositional age (Late Cretaceous or younger), suggesting that no substantial post-depositional heating has occurred. The mean track length is $11.63 \mu \mathrm{m}$, but only eight tracks were measured, so the track length data are inconclusive.

It would be unwise to speculate on the thermal history of the Northland Allochthon from one data point, but VR and clay mineralogy studies have reported exposure to maximum paleotemperatures of $120-250^{\circ} \mathrm{C}$ for these rocks (Aadil 1995). As suggested, these temperatures were achieved during burial before obduction.

\section{DISCUSSION}

The approach of using different paleotemperature indicators to evaluate the thermal history of the basin has been successfully applied to the Waitemata Basin. The fission track ages obtained from unannealed apatites were used to infer the provenance of the Waitemata Basin sediments by applying the maximum likelihood method. The data from the Waipapa Group rocks provide additional important information about the denudation history of the region during the mid Cretaceous.

Data presented from the Waitemata Basin clearly indicate that AFT ages have not been further reduced from the original cooling ages of the source areas, suggesting that the basin has remained $<60^{\circ} \mathrm{C}$ since deposition. This conclusion is in accord with the limited vitrinite reflectance results $(0.17-0.26 \%)$ from the Auckland region, which indicate that basin temperatures did not exceed c. $30^{\circ} \mathrm{C}$.

The occurrence of zeolites in the tuff and some sandstone beds may provide some evidence of transient elevated heat flow through the basin sediments. However, the range of temperatures at which zeolites can form varies from surface temperatures to $250^{\circ} \mathrm{C}$, where the time required for such reactions to occur varies from less than a week to a few million years.

Sameshima (1978) has related the occurrence of zeolites in the Waitemata Basin to hot spring activity, but the effects of any such activity on the annealing of apatites should have been significant. If the maximum temperatures were c. $200^{\circ} \mathrm{C}$ during this activity, the minimum time required for at least 5\% annealing of tracks in apatites is c. $6 \mathrm{~h}$ (Green et al. 1985; Laslett et al. 1987). It is highly unlikely that hydrothermal activity lasted for such a short duration. At $100^{\circ} \mathrm{C}$, the minimum time required for similar annealing is c. $20 \mathrm{yr}$ and at lower temperatures $\left(\mathrm{e} . \mathrm{g}, 50^{\circ} \mathrm{C}\right.$ ) the time needed is c. $55000 \mathrm{yr}$. Geological evidence suggests that hydrothermal activity normally continues for many thousands of years. The temperatures of any circulating fluids must therefore have been such that the thermal conditions in the basin did not lead to any significant annealing of fission tracks in apatite. Furthermore, the formation of zeolites is not exclusively dependent on the 

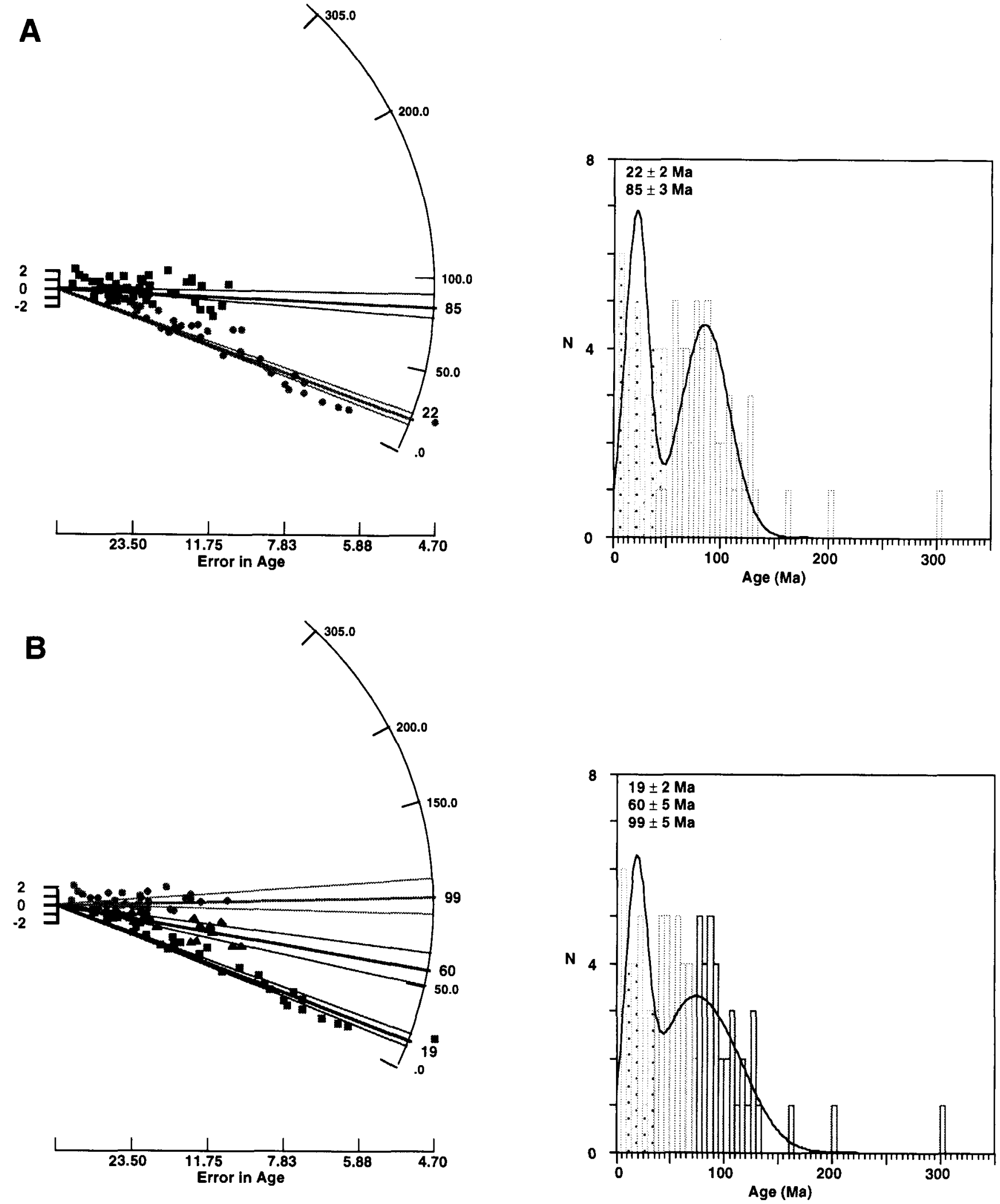

Fig. 11 Estimation of the maximum likelihood set of age populations and their mean ages using 95 apatite age measurements of samples $9105-19,-28,-29$ in the northeast region of the Waitemata Basin. The display is same as described for Fig. 5. A, Estimation of mean ages $( \pm 1 \sigma)$ assuming two populations yielded c. $22 \pm 2$ and c. $85 \pm 3 \mathrm{Ma}$ ages, indicating contemporaneous volcanism and Waipapa Group rocks as sources. B. Estimation of mean ages $( \pm 1 \sigma)$ assuming three populations yielded c. $19 \pm 2$, c. $60 \pm 5$, and c. 99 $=5 \mathrm{Ma}$ ages. The c. $19 \pm 2$ and $99 \pm 5 \mathrm{Ma}$ ages represent contemporaneous volcanism and Waipapa Group rocks as sources; however, the c. $60 \pm 5 \mathrm{Ma}$ age population is the same as found in the southern region (see text for detail). 


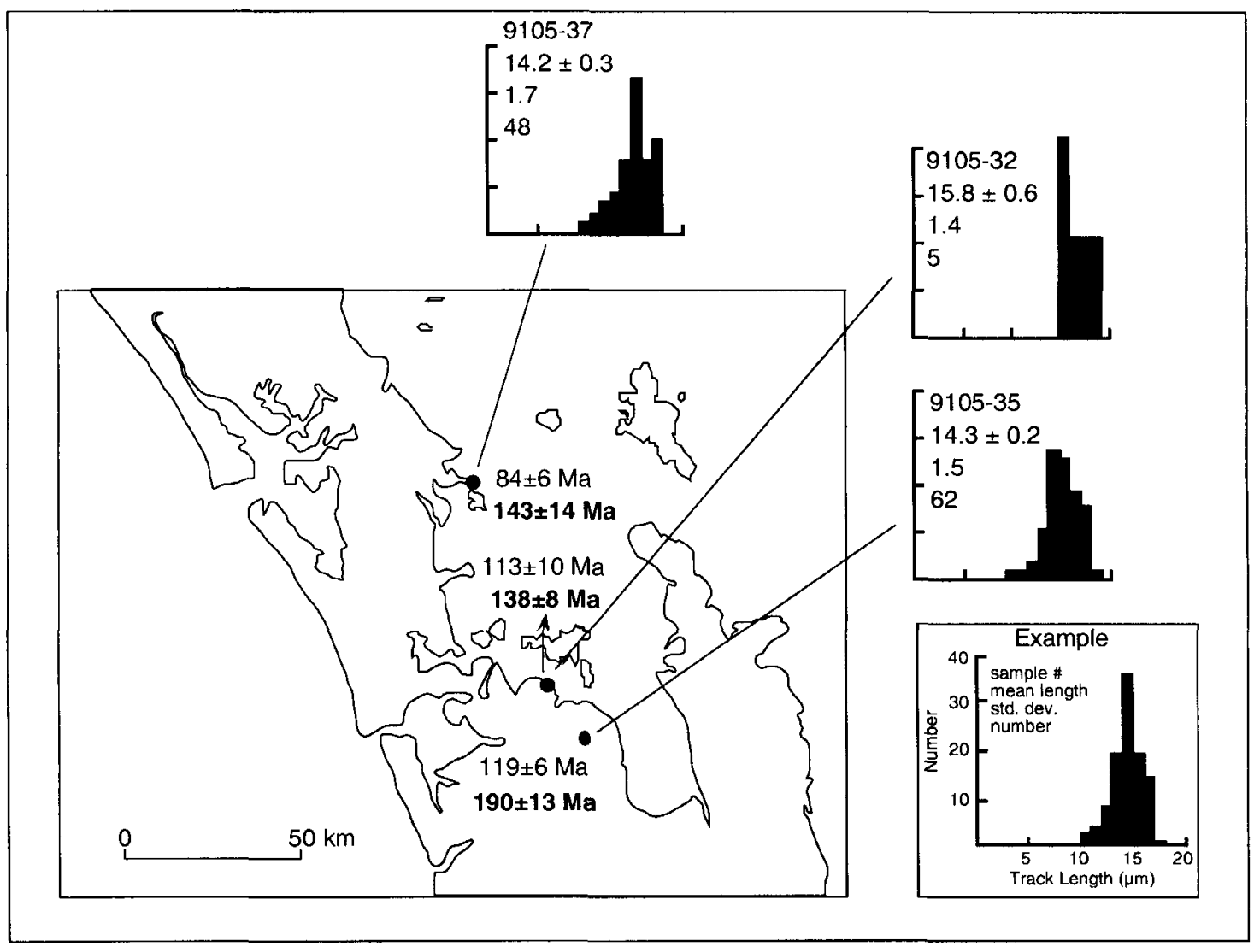

9105-32

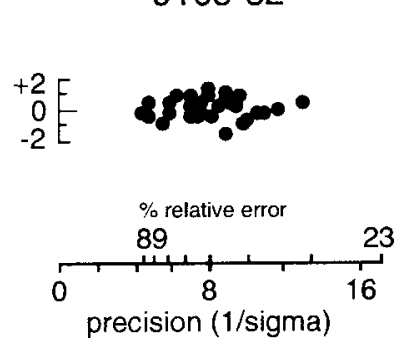

9105-35

$\left[\begin{array}{c}210 \\ -110 \\ -80 \\ 30\end{array}\right.$

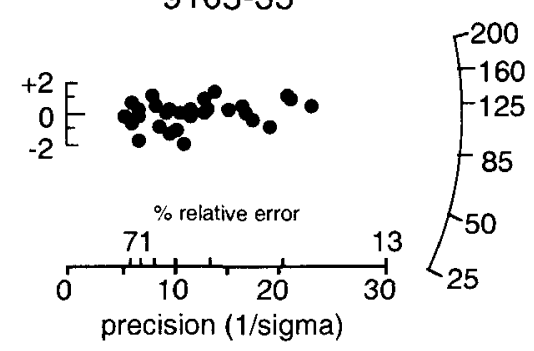

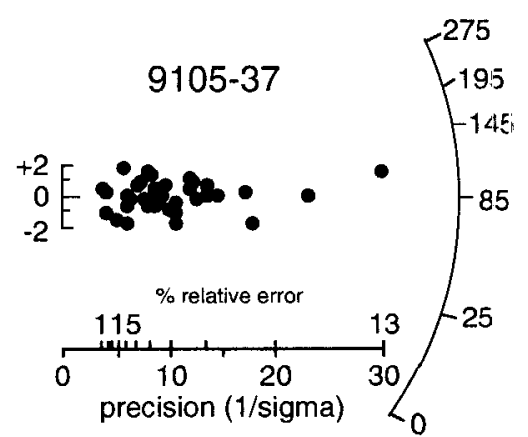

Fig. 12 AFT results for samples from basement Waipapa Group rocks and their locations. Track lengths are normalised to 100 track The scale and values on each plot are described in the example. Also shown are the ZFT results for the same samples in bold.

temperature, but also on the chemistry of the pore fluids. It is possible that formation of zeolites in the Waitemata Basin was facilitated by the chemistry of the circulating fluids at very low temperatures. Davidson \& Black (1994) concluded that the occurrence of zeolite in the Waitemata sandstone and tuffs is due to diagenetic processes that took place at temperatures $<100^{\circ} \mathrm{C}$. This is consistent with the fission track data which suggest that temperatures in the basin remained $<60^{\circ} \mathrm{C}$.

Individual apatite grain ages can be resolved into at least two populations which represent major differences in the sources of basinal apatites. The youngest population has a mean age of $19 \pm 1 \mathrm{Ma}$, which is coeval with the Miocene volcanic activity, suggesting this as a continuous source of sediment throughout the basin's depositional history.
The population of grains with a mean age of $63 \pm 2 \mathrm{Ma}$ recorded in the southern part of the basin has an unknow $n$ origin. There are no known pre-Miocene rocks in the viciniry that cooled at that time. Tectonically, during the La: Cretaceous to early Paleocene, New Zealand was driftir.; away from Australia, and it is not considered a time of major. crustal cooling. However, sediments and volcanics (ophiolites) of Late Cretaceous age are present in the Northland Allochthon. The $63 \mathrm{Ma}$ population is dominant in the southern part of the basin, in particular samples from the Amokura Formation and Mercer Sandstone. Recentl., Ballance (1995) suggested that the sediment supply for early and middle Miocene sandstones in the central, northern, and eastern North Island was either local or sourced from the north. It was only in the middle Miocene that a southerly 

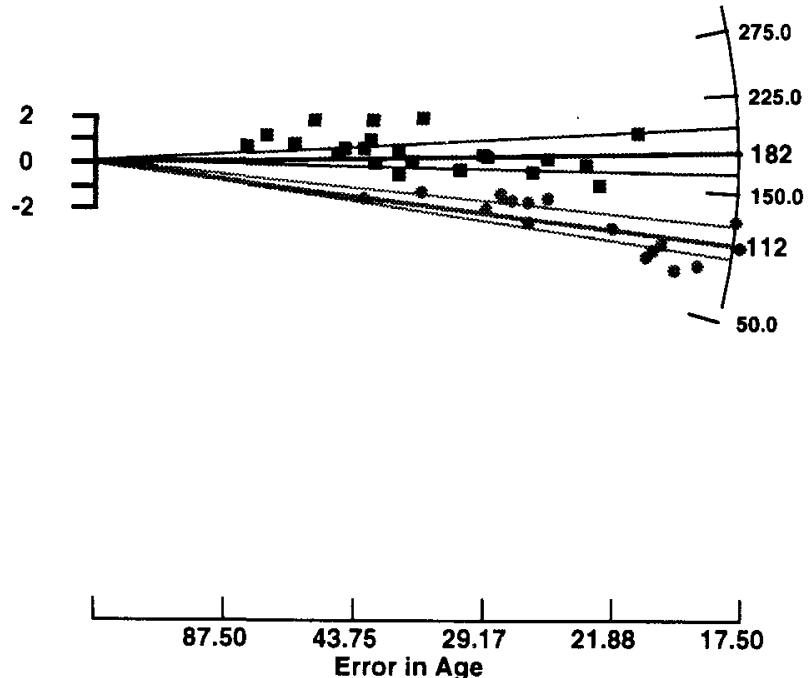

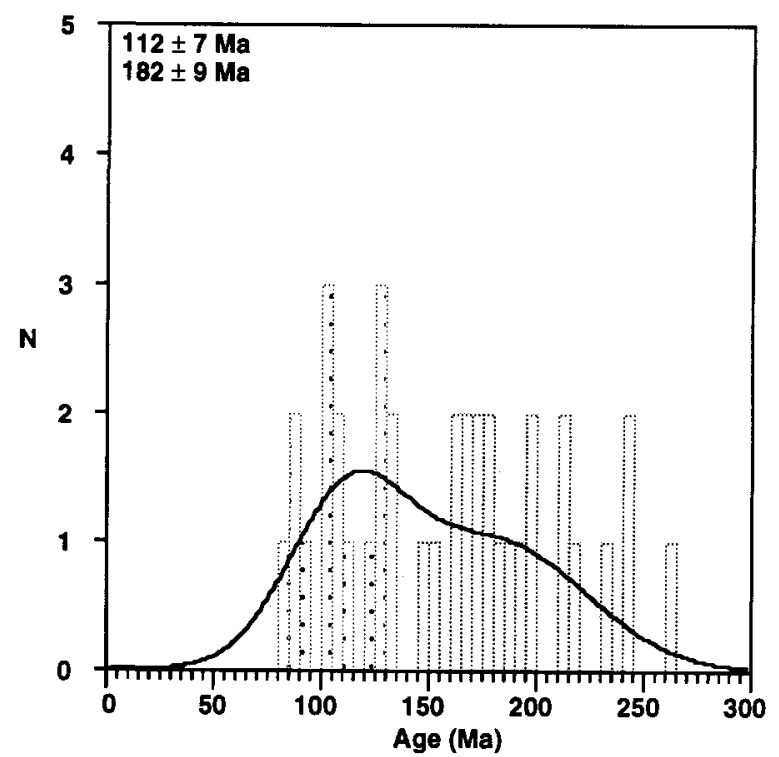

Fig. 13 Estimation of maximum likelihood set of age populations and their mean ages using 38 zircon age measurements of samples $9105-32,-35$, and -37 , from basement Waipapa Group rocks. The display is same as described for Fig. 5. This shows two populations of age c. $112 \pm 7$ and c. $182 \pm 9 \mathrm{Ma}$ (see text for detail).

source was established, becoming increasingly dominant by the Pliocene. Some of the granitic plutons in the South Island have yielded $60 \mathrm{Ma}$ AFT cooling ages (Tippett \& Kamp 1993). Other researchers also report isotopic ages of magmatic rocks from the South Island between 80 and $60 \mathrm{Ma}$ (Bishop 1992; Chamberlain et al. 1995). It is possible that a southerly source was established earlier than has been generally considered, but it is difficult to envisage how sediments derived from the South Island could bypass the Taranaki Basin during the Miocene. A possible solution to this problem is that the apatites within the Waitemata Basin are reworked detrital grains that were originally derived from the South Island during the Late Cretaceous. A more likely explanation is that they were derived from an unidentified local source.

The oldest and most significant population of apatite grains has been derived ultimately from the Waipapa Group. Samples from all parts of the basin contain this population, suggesting that the Permian-Jurassic sequence continuously supplied much of the sediment to the basin. The uniformity of these ages suggests that Waipapa Group rocks were unroofed during the Cretaceous. The limited data also suggest that two discrete periods of cooling/denudation affected the Waipapa Terrane; a major Early Cretaceous event and a later mid-Cretaceous event. Erosion of this region during the Miocene produced sediment with Earlymid Cretaceous apatite and zircon fission track ages, which subsequently was deposited within the Waitemata Basin.

The estimates of paleotemperatures from VR and clay mineralogy data for Northland Allochthon (Aadil 1995) indicate that these rocks (Late Cretaceous-Oligocene) reached temperatures of $150-250^{\circ} \mathrm{C}$ before emplacement of the allochthon during late Oligocene to early Miocene. However, the single AFT age of $113 \pm 10 \mathrm{Ma}$ from the Northland Allochthon provides conflicting evidence, as it suggests that the. Northland Allochthon rocks have never experienced paleotemperatures above c. $110^{\circ} \mathrm{C}$ (the limit of track stability in apatite). It seems likely that Northland
Allochthon rocks experienced a wide range of maximum paleotemperatures.

Apatite grains from the older populations (Late-mid Cretaceous) could therefore have been derived from either the Waipapa Group rocks or the Northland Allochthon. This would imply that the Waipapa Group rocks were high standing throughout the $100-25 \mathrm{Ma}$ period and were therefore not buried beneath the Northland Allochthon sediments. This inference supports the passive margin wedge model of Ballance (1993) for the Northland Allochthon.

Since the apatite ages from the Waipapa Group rocks were not further reduced due to burial by the overlying Miocene Waitemata Basin, and the fact that apatite ages from the basin are the same as the underlying source rocks, the maximum thickness of the basin sequence cannot have been much greater than $1 \mathrm{~km}$, as suggested by Ballance (1974). Alternatively, the paleogeothermal gradient may have been unusually low (which seems unlikely given its intra-arc location) at the time of maximum burial.

The concordance between the older AFT and the ZFT data from the Waipapa Group rocks provides conclusive evidence for a discrete cooling event during the Early Cretaceous (c. 119-113 Ma). The single sample with an apatite age of $84 \pm 6 \mathrm{Ma}$, which also has a mean track length of $14.21 \pm 0.3 \mu \mathrm{m}$, points to a second period of cooling during the mid Cretaceous. These results suggest that the rocks now exposed at the surface have cooled from maximum paleotemperatures of at least c. $250^{\circ} \mathrm{C}$, which is consistent with the degree of low-grade metamorphism. The near-concordance of zircon and apatite results suggests that cooling was rapid, at a rate of c. $180-36^{\circ} \mathrm{C} / \mathrm{m} . \mathrm{y}$, and if this cooling occurred over a span of 1-5 m.y., it implies substantial denudation (c. $10 \mathrm{~km}$ ) at a rate of $10-2 \mathrm{~mm} / \mathrm{yr}$.

The timing of the two inferred episodes of denudation is critical in terms of the tectonics of the region. In Earlymid Cretaceous time, compressive deformation reached a climax in response to the accretion of many tectonostratigraphic terranes (e.g., Ballance 1993). The earlier phase 
of denudation is most likely related to this peak in compressional tectonism. At c. $105 \mathrm{Ma}$, subduction ceased as a result of collision of the Phoenix spreading ridge, with the subduction zone extending along the eastern margin of Gondwana (Bradshaw 1989). A range of evidence suggests that extension closely followed the cessation of subduction (Tulloch \& Kimbrough 1989; Laird 1994, 1996; Muir et al. 1994). The mid Cretaceous is thus an important period in that it is the time when the tectonic regime switched from being compressional to extensional.

The younger age from the Waipapa Group rocks, $84 \pm$ $6 \mathrm{Ma}$, probably represents cooling driven by accelerated denudation related to the terminal stage of this extensional phase of deformation and the onset of seafloor spreading in the Tasman Sea. This cooling event is similar to the cooling phase documented by fission track data further south along the West Coast of South Island (White \& Green 1986; Seward 1989; Kamp et al. 1989). It is also broadly similar to a major phase of cooling recorded along the east coast of Australia (Moore et al. 1986; Dumitru et al. 1991; Raza et al. 1995, 1996). This implies crustal cooling at this time was more widespread than previously thought and affected large regions along the eastern margin of Gondwana.

These observations, and the timing of cooling indicated by the new fission track results, suggest that the maximum temperatures were achieved at some time during the Early Cretaceous, before cooling during the mid Cretaceous, possibly involving two discrete phases of cooling. This cooling was accompanied by substantial denudation (c. $10 \mathrm{~km}$ ), which is most likely associated with compressional tectonism and uplift along the eastern margin of Gondwana, and subsequent extensional tectonism that followed soon after

\section{ACKNOWLEDGMENTS}

This publication forms part of the senior author's PhD work. Members of the fission track research group at La Trobe University are thanked for useful discussions. Staff at The University of Auckland and The University of Waikato are thanked for their assistance during the senior author's stay in New Zealand. Irradiation costs were met from a grant from The University of Waikato Research Committee. Thanks are also due to Philippa Black for allowing the senior author to generate VR data in her laboratory. This paper was improved by constructive reviews by Bruce Hayward, Barry Kohn, Brian Ricketts, and an anonymous reviewer.

\section{REFERENCES}

Aadil, N. 1995: Burial diagenesis of Northland Allochthon rocks, Northland Basin, North Island, New Zealand. Unpublished $\mathrm{PhD}$ thesis, lodged in the Library, University of Auckland, Auckland, New Zealand.

Ballance, P. F. 1974: An inter-arc flysch basin in northern New Zealand: Waitemata Group (upper Oligocene to lower Miocene). Journal of Geology 82: 439-471.

Ballance, P. F. 1976: Stratigraphy and bibliography of the Waitemata Group of Auckland, New Zealand. New Zealand Journal of Geology and Geophysics 19: 897-932.

Ballance, P. F. 1988: Late Cenozoic time-lines and calc-alkaline volcanic arcs in northern New Zealand-further discussion. Journal of the Roval Society of New Zealand 18: 347-358.
Ballance, P. F. 1993: The paleo-Pacific, post-subduction, passive margin thermal relaxation sequence (Late CretaceousPaleogene) of the drifting New Zealand continent. In Ballance, P. F. ed. South Pacific sedimentary basins Amsterdam, Elsevier Science Publishers B.V. Pp. 93-1 10

Ballance, P. F. 1995: Neogene sandstone provenance, North Island and its tectonic significance (Abstract). Geological Societ of New Zealand Miscellaneous Publication 81A: 74.

Ballance, P. F. in press: Simplification of the Southwest Pacific Neogene arcs: inherited complexity and control by :i retreating pole of rotation. In: Ryan, P.; Mac Niocaill, $\mathrm{C}$ ed. Continental tectonics. Geological Society of London Special Publication.

Ballance, P. F.; Gregory, M. R. 1991: Parnell Grits--large subaqueous volcaniclastic gravity flows with multiple particle-support mechanisms. Society of Economi Paleontology and Mineralogy Special Publication 45 189-200.

Ballance, P. F.; Spörli, K. B. 1979: Northland Allochthon. Journa: of the Royal Society of New Zealand 24: 427-438.

Ballance, P. F.; Pettinga, J. R.; Webb, C. 1982: A model of the Cenozoic evolution of northern New Zealand and adjacent areas of the southwest Pacific. Tectonophysics 87: 37-48

Bishop, D. J. 1992: Extensional tectonism and magmatism during the middle Cretaceous to Paleocene, North Westland, Nev. Zealand. New Zealand Journal of Geology and Geophysic., 35: 81-91.

Black, P. M. 1989: Regional metamorphism in basement Waipap: Group, Northland, New Zealand. Royal Society of Nen Zealand Bulletin 26: 15-21

Black, P. M.; Clark, A. S. B.; Hawke, A. A. 1993: Diagenesis anc very low-grade metamorphism of volcaniclastic sandstone: from contrasting geodynamic environments, North Island. New Zealand: the Murihiku and Waipapa terranes. Journa of Metamorphic Geology 11: 429-435.

Bradshaw, J. D. 1989: Cretaceous geotectonic pattern in the N\& Zealand region. Tectonics 8: 803-820.

Brothers, R. N. 1974: Kaikoura Orogeny in Northland, Nev. Zealand. New Zealand Journal of Geology and Geophysic, 17: 1-18.

Brothers, R. N. 1986: Upper Tertiary and Quaternary volcanisn and subduction zone regression, North Island, Nev. Zealand. Journal of the Royal Society of New Zealand 16 275-298.

Burnham, A. K.; Sweeney, J. J. 1989: A chemical kinetic mode of vitrinite maturation and reflectance. Geochimica $\epsilon$ Cosmochimica Acta 53: 2649-2657.

Chamberlain, C. P.; Zeitler, P. K.; Cooper, A. F. 1995: Geo chronologic constraints of the uplift and metamorphisn: along the Alpine Fault, South Island, New Zealand. New Zealand Journal of Geology and Geophysics 38: 515-523

Coombs, D. S.; Ellis, A. J.; Fyfe, W. S.; Taylor, A. M. 1959: Th. zeolite facies with comments on the interpretation of hydrothermal synthesis. Geochimica et Cosmochimici. Acta 17: 53-107.

Davidson, K. J.; Black, P. M. 1994: Diagenesis in Early Miocen. Waitemata Group sediments, Upper Waitemata Harbold Auckland, New Zealand. Geoscience Reports Shizuok: University 20: 135-142.

Dumitru, T. A.; Hill, K. C.; Coyle, D. A.; Duddy, I. R.; Foster. D. A.; Gleadow, A. J. W.; Green, P. F.; Kohn, B. P.; Laslett. G. M.; O'Sullivan, A. J. 1991: Fission track thermo chronology: application to continental rifting of south eastern Australia. APEA Journal 3I: 131-142.

Gleadow, A. J. W. 1981: Fission-track dating methods: What ar the real alternatives? Nuclear Tracks and Radiatio Measurements 5: 3-14. 
Gleadow, A. J. W.; Duddy, I. R.; Green, P. F.; Hegarty, K. A. 1986: Fission track lengths in the apatite annealing zone and the interpretation of mixed ages. Earth and Planetary Science Letters 78: 245-254.

Green, P. F.; Duddy, I. R.; Gleadow, A. J. W.; Tingate, P. T.; Laslett, G. M. 1985: Fission track annealing in apatite: track length measurements and form of the Arrhenius plot. Nuclear Tracks 10:323-328.

Green, P. F.; Duddy, I. R.; Gleadow, A. J. W.; Lovering, J. F. 1989: Apatite fission track analysis as a palaeotemperature indication for hydrocarbon exploration. In: Naeser, N. D. $e d$. Thermal history of sedimentary basins-methods and case histories. New York, Springer-Verlag. Pp. 181-195.

Green, P. F.; Hegarty, K. A.; Duddy, I. R.; Foland, S. S.; Gorbachev, V. 1996: Geological constraints on fission track annealing in zircon. Abstract. International workshop on fission track dating, Gent. P. 44.

Hayward, B. W. 1979: Eruptive history of the early to mid Miocene Waitakere Volcanic arc and paleogeography of the Waitemata Basin, northern New Zealand. Journal of the Royal Society of New Zealand 9: 297-320.

Hayward, B. W. 1993: The tempestuous 10 million year life of a double arc and intra-arc basin-New Zealand's Northland Basin in the Early Miocene. In: Ballance, P. F. ed. South Pacific sedimentary basins. Amsterdam, Elsevier Science Publishers B.V. Pp. 113-142.

Hayward, B. W.; Smale, D. 1992: Heavy minerals and the provenance history of Waitemata Basin sediments (early Miocene, Northland, New Zealand). New Zealand Journal of Geology and Geophysics 35: 223-242.

Hayward, B. W.; Brook, F. J.; Isaac, M. J. 1989: Cretaceous to Middle Tertiary stratigraphy, paleogeography and tectonic history of Northland, New Zealand. Royal Society of New Zealand Bulletin 26: 47-64.

Herzer, R. H. 1995: Seismic stratigraphy of a buried volcanic arc, Northland, New Zealand and implications for Neogene subduction. Marine and Petroleum Geology 12: 511-531.

Hurford, A. J. 1986: Cooling and uplift patterns in the Lepontine Alps, south central Switzerland, and an age of vertical movement on the Insubric fault line. Contribution to Mineral Petrology 92: 413-427.

Iijima, A. 1988: Diagenetic transformations of minerals as exemplified by zeolites and silica minerals - a Japanese view. In: Chilingarian, G. V.; Wolf, K. H. ed. Diagenesis, II. New York, Elsevier. Pp. 147-211.

Isaac, M. J.; Herzer, R. H.; Brook, F. J.; Hayward, B. W. 1994: Cretaceous and Cenozoic sedimentary basins of Northland, New Zealand. Institute of Geological \& Nuclear Sciences Monograph 8. 203 p.

Jennings, W. 1989: Metamorphism in the Waipapa Terrane. Omahuta and Puketi Forests, Northland, New Zealand. Royal Society of New Zealand Bulletin 26: 23-28.

Kamp, P. J. 1984: Neogene and Quaternary extent of the subducted plate beneath North Island, New Zealand: implications for Kaikoura tectonics. Tectonophysics 108: 241-266.

Kamp, P. J. J. 1986a: Late Cretaceous-Cenozoic tectonic development of the southwest Pacific region. Tectonophysics 121: 225-251.

Kamp, P. J. 1986b: The mid-Cenozoic Challenger Rift system of western New Zealand and its implication for the age of Alpine Fault inception. Geological Society of America Bulletin 97: 255-281.

Kamp, P. J. J.; Green, P. F; White, S. H. 1989: Fission track analysis reveals character of collisional tectonics in New Zealand. Tectonics 8: 169-195.

Kear, D. 1994: A "least complex" dynamic model for late Cenozoic volcanism in the North Island, New Zealand. New Zealand Journal of Geology and Geophysics 37: 223-236.
Krishnaswami, S.; Lal, D.; Prabhu, N.; McDougall, D. 1974: Characteristics of fission tracks in zircons: application to geochronology and cosmology. Earth and Planetary Science Letters 22: 51-59.

Laird, M. G. 1994: Geological aspects of the opening of the Tasman Sea. In: Van der Lingen, G. J.; Swanson, K. M.; Muir, R. J. ed. Evolution of the Tasman Sea Basin. Rotterdam/ Brookfield, A.A. Balkema. Pp. 1-17.

Laird, M. G. 1996: Mid and early Late Cretaceous break-up basins of the South Island, New Zealand. In: Mesozoic geology of the eastern Australian plate. Geological Society of Australia Extended Abstract 43: 329-336.

Laslett, G. M.; Green, P. F.; Duddy, I. R.; Gleadow, A. J. W. 1987: Thermal annealing of fission tracks in apatite, 2. A quantitative analysis. Chemical Geology (Isotope Geoscience Section) 65: 1-13.

Moore, M. E.; Gleadow, A. J. W.; Lovering, J. F. 1986: Thermal evolution of rifted continental margins: new evidence from fission tracks in basement apatites from southeastern Australia. Earth and Planetary Science Letters 78 : 255-270.

Muir, R. J.; Ireland, T. R.; Weaver, S. D.; Bradshaw, J. D. 1994: Ion microprobe $\mathrm{U}-\mathrm{Pb}$ zircon geochronology of granitic magmatism in the Western Province of the South Island, New Zealand. Chemical Geology (Isotope Geoscience Section) 113: 171-189.

Nelson, C. S. 1978: Stratigraphy and paleontology of the Oligocene Te Kuiti Group, Waitomo County, South Auckland, New Zealand. New Zealand Journal of Geology and Geophysics 21: $553-594$.

Nicholson, K. 1995: The age of the Poor Knights Islands, the Mokohinau Islands and Gt Barrier Island (Abstract). Geological Society of New Zealand Miscellaneous Publication 81A: 157

Raza, A.; Hill, K. C.; Korsch, R. J. 1995: Mid-Cretaceous regional uplift and denudation of the Bowen-Surat Basins, Queensland and its relation to Tasman Sea rifting. In: Supplement to Follington, I. L.; Beeston, J. W.; Hamilton, L. H. ed. Bowen Basin Symposium 1995 Proceedings. Geological Society of Australia. Pp. 1-8.

Raza, A.; Hill, K. C.; Korsch, R. J.; Brown, R. W. 1996: Mesozoic denudation and tectonics of the central eastern margin of Australia: fission track thermochronology. In: Mesozoic geology of the eastern Australia Plate. Geological Society of Australia Extended Abstract 43: 464-475.

Ricketts, B. D.; Ballance, P. F.; Hayward, B. W.; Mayer, W. 1989: Basal Waitemata Group lithofacies: rapid subsidence in an early Miocene interarc basin, New Zealand. Sedimentology 36: 559-580.

Sambridge, M. S.; Compston, W. 1994: Mixture modelling of multi-component data sets with application to ion-probe zircon ages. Earth and Planetary Science Letters 128: 373-390.

Sameshima, T. 1978: Zeolites in tuff beds of the Miocene Waitemata Group, Auckland Province, New Zealand. In: Sand, L. B.; Mumpton, F. A. ed: Natural zeolites: occurrence, properties, use. New York, Pergamon Press. Pp. 309-317.

Seward, D. 1989: Cenozoic basin histories determined by fissiontrack dating of basement granites, South Island, New Zealand. Chemical Geology (Isotope Geoscience Section) 79: $31-48$.

Smith, I. E. M.; Ruddock, R. S.; Day, R. A. 1989: Miocene arctype volcanic/plutonic complexes of the Northland Peninsula, New Zealand. Royal Society of New Zealand Bulletin 26: 205-213. 
Spörli, K. B. 1978: Mesozoic tectonics, North Island, New Zealand. Geological Society of America Bulletin 89: 415-425.

Spörli, K. B. 1989a: Exceptional structural complexity in turbidite deposits of the piggy-back Waitemata Basin, Miocene, Auckland/Northland, New Zealand. Royal Society of New Zealand Bulletin 26: 183-194.

Spörli, K. B. 1989b: Tectonic framework of Northland, New Zealand. Royal Society of New Zealand Bulletin 26: 3-13.

Spörli, K. B.; Ballance, P. F. 1989: Mesozoic-Cenozoic ocean floor/continent interaction and terrane configuration, SWPacific area around New Zealand. In: Ben Avraham, Z. ed: The evolution of the Pacific Ocean margins. Oxford Monographs on Geology and Geophysics 8: 176-190.

Tippett, M. J.; Kamp, P. J. J. 1993: Fission track analysis of the Late Cenozoic vertical kinematics of continental Pacific crust, South Island, New Zealand. Journal of Geophysical Research 98: 16119-16148
Tulloch, A. J.; Kimbrough, D. L. 1989: The Paparoa Metamorphi: Core Complex, New Zealand: Cretaceous extensio: associated with fragmentation of the Pacific margin o Gondwana. Tectonics 8: 1217-1234.

Weissel, J. K.; Hayes, D. E. 1977: Evolution of the Tasman Se reappraised. Earth and Planetary Science Letters 36 $77-84$.

White, P. J.; Waterhouse, B. C. 1993: Lithostratigraphy of the 'Г: Kuiti Group: a revision. New Zealand Journal of Geolog. and Geophysics 36: 255-266.

White, S. H.; Green, P. F. 1986: Tectonic development of the Alpin. fault zone, New Zealand: a fission-track study. Geolog 14: 124-127.

Wright, A. C.; Black, P. M. 1981: Petrology and geochemistry o Waitakere Group, North Auckland, New Zealand. $N^{\prime}$ ' Zealand Journal of Geology and Geophysics 24: 155-16.5

Yamada, R.; Takahiro, T.; Nishimura, S.; Ito, H. 1995: Annealin: kinetics of fission tracks in zircon: an experimental study Chemical Geology (Isotope Geoscience Section) 122 249-258. 